\title{
La moneda como ofrenda en los manantiales
}

\author{
Manuel Abad Varela *
}

A nadie se le escapa, y no vamos a pormenorizarlo ahora, la importancia que ha tenido desde la antigüedad el culto a las aguas en la península ibérica, principalmente en el NW y zona céltica, y en el Levante ibérico, como hace tiempo nos señaló el profesor Blázquez ${ }^{1}$. Podemos decir que es una realidad que está atestiguada desde la Edad del Bronce, incluso con ofrendas ${ }^{2}$.

Actualmente nos encontramos a menudo con afirmaciones de que en Hispania los romanos, además de otros ex-votos, se servían de las monedas para hacer ofrendas a las divinidades de las fuentes ${ }^{3}$. A esta idea enseguida asociamos la imagen, frecuente en nuestros dias, de contemplar como hay visitantes que las arrojan en fuentes, manantiales o no, y principalmente en aguas estancadas ${ }^{4}$. Pienso que no es necesario enumerar ejemplos. A este fenómeno, según se dice, hay que acompañarlo de alguna petición que la superstición popular, en el mejor de los casos, espera que se cumpla. Asi tenemos que cuando se arroja una o varias

* Departamento de Prehistoria e H. Antigua. U.N.E.D. Madrid.

1 Blázquez, J. M., «Le culte des Eaux dans la Péninsule Ibérique», OGAM, IX, 1957, págs. 209-233; y «Aportaciones al estudio de las religiones primitivas de España», AEA, XXX, 1957.

${ }^{2}$ Puede consultarse como ejemplo el trabajo de López CueVILLAS, F., «Armas de bronce ofrendadas al río Sil», Zephyrvs, VI, 1955, págs. 230-240, o el de Monteagudo, L., "Galicia legendaria y arqueológica. Problemas de las ciudades asolagadas», C.S.I.C. Centro de Estudios de Etnologia Peninsular. Madrid 1957.

${ }^{3}$ Recuerdo, como ejemplo, lo que escribió José M. Álvarez Martínez al hablar sobre las termas de Alange: «Los enfermos curados o aliviados por las aguas expresaban su gratitud por medio de ex-votos, algunos de ellos de muy buena factura, aras votivas, o bien arrojando a las fuentes monedas valiosas, costumbre ésta muy atestiguada en la Galia, aunque también en Hispania” (Alange y sus termas romanas. Badajoz, 1973, pág. 42).

${ }^{4}$ Esta circunstancia se da también en aljibes, pues pude contemplar, no hace mucho, en La Coruña como la gente echaba monedas al que existe en el castillo de San Antón, actual Museo Arqueológico. 
monedas se suele hacer una petición que va ligada a un deseo subjetivo o general, como volver a visitar el lugar y se espera que, tras haber hecho la ofrenda, al final se cumpla.

Contemplado asi el fenómeno, es fácil pensar que nos encontramos ante una reminiscencia del pasado. Efectivamente, algo ha debido perdurar, aunque muy evolucionado, de las primitivas motivaciones puesto que al final la acción es más o menos la misma.

Pues bien, nuestra intención con este trabajo es conocer si se dieron estas ofrendas en la Península y en que momentos. Para ello revisamos las fuentes escritas y los hallazgos arqueológicos con el fin de saber hasta que punto se puede afirmar que en la Península Ibérica se produjo la acción de arrojar monedas como ofrendas a las aguas, al igual que en la Galia y en Italia ${ }^{5}$. Seleccionados todos aquellos casos conocidos en los que pudo darse esta motivación, confeccionamos un catálogo que nos sirviese para cuantificar y relacionar cada uno de los casos.

\section{FUENTES ESCRITAS}

Desde el inicio de la romanización, el caracter sagrado de las aguas se nos ha testimoniado a través de numerosas inscripciones romanas sobre aras votivas que nos señalan la pervivencia del culto a divinidades indígenas de las aguas, ya sea en rios, pantanos o fuentes. Tras una mayor romanización, se tendió a vincularlas con divinidades romanas, ninfas y genios $e$, incluso algunas veces con apelativo indígena. Pero, sobre todo, será en las fuentes que gozaban de tener propiedades curativas, donde los dedicantes se sintieron más obligados a depositar estas aras. En el NW las tenemos dedicadas a divinidades indigenas como Bormanicvs, Conventina, Deganta, etc., y otras dedicadas a ninfas o genios con nombre romano y epiteto indígena, como la de NYMP(hi)S / BOELI / VS RVF / VS PRO / SALVTE / [S] VA V(otum) S(olvit) (C.I.L., II, 2530) o la de FONTIS SAGINEES GENIO / BROCCI L(ibertus) VIP[A]ST(ianus) / ALEXIS

\footnotetext{
${ }^{5}$ TheVenot, E., Dieux et Sanctuaires de la Gaule. Paris 1968; MARCHI, L., La stipe tributata alle acque Apollinari. Roma 1852.
} 
AQVILEGVS / V(votum) S(olvit) L(ibens) M(erito) (C.I.L., II, 5726) ${ }^{6}$. No quiere ésto decir que todas las divinidades que se citan en las aras sean autóctonas, pues en algunas se ve que sus dedicantes proceden de zonas mucho más alejadas.

Tampoco hay que pensar que durante la etapa romana otras zonas peninsulares eran ajenas a este culto. Existe, como ejemplo, una inscripción apenas conocida de un ara votiva dedicada a otra fuente termal de la antigua Nescania (cerca de Antequera, Málaga) reseñada en el siglo $X V I I^{7}$. Pero debemos reconocer que es en el área NW, la zona céltica, donde más aparecen. En este lugar es también donde las fuentes, entre otros objetos naturales, han desempeñado y lo siguen haciendo en la actualidad su papel dentro de las fábulas y creencias populares ${ }^{8}$.

En época romana, el culto a estas divinidades, con el fin de dar cumplimiento a un voto o librarse de algún mal, no se realizaba de una forma simple y espontánea sino que formaba parte de un proceso que no estaba del todo regularizado ya que dependía de cada caso y lugar. En ellos solian intervenir los augurios y ritos, de acuerdo con lo que se pretendiese. Recordemos el caso del rico agricultor Valesio que nos cuenta Valerio Máximo ${ }^{9}$, o toda la simbología que nos representa la conocidísima pátera de plata de Otañes ${ }^{10}$. Sin embargo, las fuentes escritas referidas a Hispania nada añaden a este tipo de cultos. Plinio, aunque nos da una pormenorizada explicación sobre los poderes y virtudes de los distintos tipos de aguas (libro XXXI), sólo centró su atención en aquellas donde se pro-

\footnotetext{
${ }^{6}$ Se pueden consultar sobre este particular los trabajos de López CueVILLAS, F., La civilización céltica de Galicia, (reedición de la de 1953). Madrid 1989, págs. 292-297; BLÁzouez, J. M., “Opus cit.», 1957, págs. 209-233; SCHULTEN, A., Geografia y etnografia antiguas de la peninsula Ibérica, vol. II. Madrid 1963, págs. 100-113; ToRres Rodriguez, C., La Galicia romana. La Coruña 1982, págs. 154-156; y Garcia Fernandez-Albalat, B., "Las Ilamadas divinidades de las aguas", en Bermejo BarrerA, J. C., Mitología y mitos de la Hispania prerromana, 2, ed. Madrid Akal/Universidad, 1986, págs. 141-192. En la obra dirigida por Mangas, J., Hispania Epigraphica, 1. Madrid 1990, nos encontramos con algunas más.

7 FONTI. DIVO. / ARAM. L. POST / HVMIVS. SATVL. / IVS. EX. VOTO / D.D.D. en CARTER, F., Viaje de Gibraltar a Málaga (traducción de C. Taylor y J. A. Olmedo de la obra: A journay from Gibraltar to Málaga de 1777). Málaga 1981, págs. 201-202.

${ }^{8}$ Sobre el papel que ha jugado y juega el agua y las fuentes en la actualidad, ver MEnéndez Pelayo, M., Historia de los Heterodoxos, vol. I. Madrid 1956, ed. BAC, págs. 326-328; o las leyendas relacionadas con ellas donde se encuentran tesoros: LoPEz CUEVILLAS, F., «O culto das fontes no noroeste hispánico". Trabalhos da Sociedade Portuguesa de Antropologia e Etnologia, VII, fasc. II-III, 1935, págs. 73-104, y Frutos García, Pedro de, Leyendas gallegas, "De Breogán al fin del mundo». Madrid 1980, págs. 139-140, «El tesoro de Bretoña», o sobre "Leyendas religiosas», págs. 146 y 147.

${ }^{9}$ Valerius Maximus: Factorum et dictorum memorabilium libri, II, cap. IV, 5.

${ }^{10}$ MELIDA, J. R., «Pátera de plata descubierta en el valle de Otañes», RABM, I. 1897, págs. 289-301.
} 
ducian ciertos fenómenos incomprensibles, como es el caso de las fuentes Tamáricas (XXXI, 23-24), porque sus aguas al manar o dejar de hacerlo sin ningún control servían de augurio.

Pero si el dedicante de un ara era capaz de sufragar los gastos de fabricación y cumplir con los ritos como signo de agradecimiento hacia la divinidad, le resultaria más fácil ofrecer alguna moneda o stips. Este era el término utilizado por los romanos para denominar a estas ofrendas, es decir, eran las monedas de bronce de poco valor que se acostumbraba a entregar como donativo o limosna (Digesto, XLVII, XX, 1). Así nos lo acreditan las fuentes escritas, pues en otro pasaje del Digesto ( $L, X V I, 27)$, hablando del stipendium, se recoge el sentido del término stips dado a moneda de corto valor, "Stipendium" a stipe appellatum est, quod per stipes, id est modica aera colligatur, que incluso se asimilan a tributo de contribución, o con lo que se contribuye para pagar a los militares, según el decir del jurista Pomponio.

El comentario que J. Toutain hizo sobre esta palabra para el Diccionario de Daremberg y Saglio ${ }^{11}$, nos da abundante información sobre la costumbre que tenian los romanos de arrojar pequeñas monedas a los rios, lagos y fuentes, además de entregarlas como limosna o contribución voluntaria para las necesidades de un templo o, incluso, para ayuda en la financiación de una obra pública. Varios autores clásicos, como Cicerón, T. Livio, Séneca, Plinio el Joven, Suetonio o Julio Obsecuente, reflejan de algún modo esta costumbre ${ }^{12}$. De hecho, la acción stipem o stipes jacere o stipem ponere encierra consigo este significado, como lo prueban los grafitos dedicados a divinidades hechos sobre monedas griegas o sobre un semis etrusco. Pero el más claro exponente del significado de ex-voto que tenían las monedas es un as romano, muy gastado, dedicado a la diosa Fortuna. En el anverso se ven las letras S F gravadas con

\footnotetext{
Daremberg, CH. y Saglio, CDM., Dictionnaire des Antiquités Grecques et Romaines, vol. IV, 2. ${ }^{\text {a }}$ parte. Paris 1911 (reedición en Graz, 1969).

${ }^{12}$ Cicerón: De Leg. II, IX, 22, nos dice: Praeter ldaeae Matris famulos eosque iustis diebus ne quis stipem cogito y en el II, XVI, 40, Stipem sustulimus, nisi eam quam ad paucos dies propriam Idaeae Matris excepimus; Tito Livio en Ab Urbe Condita, V, 25, 5; XXV, 12, 14; y XXVII, 37, 9, hace referencia al stips; Séneca en De Benef. VII, 4, 6, nos refiere Omnia deorum sunt; tamen et diis et donum posuimus et stipem iecimus; Plinio el Joven en la Epist. VIII, 8, nos dice que las aguas del río Clitumnus estaban tan claras y transparentes que se podrian contar las piezas de monedas arrojadas; Suetonio en De vita dvodecim Caesarvm., Divus Augustus, II, 57, 1, nos señala que Omnes ordines in lacum Curti quotannis ex voto pro salute eius stipem iacebant; y Julio Obsecuente en su Liber Prod. CIII, CVI y CXIII, recogiendo los prodigios referidos por Tito Livio, nos cuenta tres casos en los que ante unos hechos extraordinarios el pueblo ofrecía una moneda a Ceres y Proserpina y en uno de ellos de acuerdo con las respuestas de los arúspices (stips Cereris et Proserpinae). Asi como existen también referencias en inscripciones (Eph. Epigr. III, págs. 314-316).
} 
punzón en la cabeza de Jano, y en el reverso, en donde apenas se ve la proa, se lee en dos líneas, igualmente gravadas ${ }^{13}$ :

\author{
FO R W A I \\ STIPE
}

\title{
FUENTES ARQUEOLÓGICAS
}

El hecho de arrojar pequeñas ofrendas, stipes, a las aguas está atestiguado por las fuentes escritas, pero también lo vamos a encontrar probado por la arqueología. No obstante, tenemos que ser conscientes de las dificultades que encierra el descubrir estos hallazgos. Por ley natural, suele suceder que las monedas que se arrojan cumplen su función para el dedicante, pero tanto si no se ven como si se ven no tardan mucho en ser recogidas por otras personas, dando lugar al desarrollo de una cadena en la que unos son los que las echan y otros los que las recogen, a no ser que por su insignificancia no merezca la pena recuperarlas. De todas ellas únicamente se encontrarán las que quedaron escondidas entre grietas o camufladas en el fondo de ríos, lagos o fuentes.

Por tal razón debemos pensar que es excepcional que nos llegue un yacimiento de estas características, virgen y anclado en el tiempo. Si acaso, podremos encontrar aquellas monedas que por las condiciones mencionadas anteriormente del lugar, profundidad del estanque, fango, grietas o temperatura de las aguas hayan impedido anteriormente su recuperación. Únicamente en el caso de que se intente limpiar o profundizar los manantiales para mejorar el caudal de extracción de sus aguas, será cuando podamos recoger monedas y aras al ser un espacio reducido. Asi es, al menos, como han aparecido en la mayoría de los casos. Reconocemos que es más complicado encontrarlas en ríos o lagos, pues al haber quedado dispersas son más difíciles de localizar. Además, los hallazgos en rios pueden justificarse por muy diversas razones con lo que resulta complicado demostrar que han servido de ofrenda en algún momento. La única manera de obtener una información positiva será dando a conocer además de las monedas recogidas en todos estos lugares, todos los de-

\footnotetext{
13 Babelón, E., Traité des monnaies grecques ef romaines. Paris 1901-1932 (Reimpreso 1965-1967), vol. I, págs. 673-679.
} 
talles que permitan justificar el hallazgo. Sin embargo, somos conscientes al hablar de este fenómeno que el principal impedimento para el conocimiento y estudio de estas posibles ofrendas es que cuando se producen se silencian. Si alguien se entera y quiere darlo a conocer, las monedas han corrido más y se encuentran ya desperdigadas, con lo que resulta poco menos que imposible conseguir que le enseñen alguna pieza. El mal ya es irreparable. Al final y si hay suerte, de todo un depósito se conseguirá información únicamente de cuatro o cinco.

Pero no quisiéramos dejar sin indicar que todas las ofrendas que se hicieron a las aguas no han tenido por qué ser forzosamente stipes, es decir, monedas de bronce de poco valor, como semises, ases o dupondios, sino que se arrojaron sestercios y monedas de plata y oro, como denarios, aureos o sólidos, como se desprende de las noticias recibidas de algunos de los hallazgos aunque sin precisar los datos para su clasificación. Tampoco se puede mantener que la totalidad de las monedas recogidas en fuentes, ríos o lagos han sido en su origen una ofrenda, sino que alguna pudo haber sido arrojada, $\sin$ más ${ }^{14}$, o se le cayó a algún bañista en un descuido, como debió ocurrir con las monedas modernas encontradas en el Balneario de Alceda.

Conocidas estas limitaciones se comprenderá la inseguridad de la información y el que hablemos siempre de posibles ofrendas.

Pues bien, a pesar de todo, hemos buscado y seleccionado en un principio todos aquellos hallazgos monetarios que se han producido en fuentes termales, lagunas y ríos que presentan indicios, más o menos claros, de ser posibles ofrendas. Con ellos confeccionamos un catálogo de estos lugares, siguiendo su situación geográfica en la Península de Oeste a Este y de Norte a Sur. En cada uno indicamos el tipo de agua y temperatura de los manantiales, al igual que citamos las inscripciones de las aras votivas relacionadas con ellos.

\section{HALLAZGOS CONSIDERADOS COMO POSIBLES OFRENDAS}

1. Balneario de Cuntis (Santa Maria, Cuntis, Pontevedra). Sus aguas son sulfurado-sódicas y alcanzan una temperatura entre sus fuentes de $27^{\circ}$ a $57^{\circ}$ C. ${ }^{15}$.

\footnotetext{
${ }^{14}$ Recuerdo, como ejemplo, lo ocurrido con un depósito monetario del siglo iv, recientemente descubierto en Villarino (Villablino, León), que al encontrarlo unos niños se dedicaron a lanzar muchas de sus monedas al rio Sil.

${ }^{15}$ Para el tipo de aguas y temperatura que mantiene cada fuente he seguido, siempre
} 
En 1908 con la intención de reparar la arqueta donde nace una de las fuentes termales se procedió a achicar el agua con una potente bomba. Mientras, numerosos operarios levantaban las losas que cubrian la fuente termal y se procedía a limpiarla. Fue entonces cuando se recogieron no menos de quinientas monedas en tan mal estado de conservación que la mayoria se deshacian al intentar limpiarlas ${ }^{16}$. Todas ellas se esparcieron entre los espectadores a los que llamó la atención.

Aquellas monedas de las que nos ha llegado información a través del jesuita Celestino García, son:

1. As frustro.

2. As de Tiberio acuñado en Caesaraugusta el año 31 d. C. (VILlaRONGA, L., Numismática antigua de Hispania, Barcelona 1979, pág. 284, tipo $8^{\circ}$. A partir de ahora esta obra se citará por VILLARONGA).

3. As de Tiberio acuñado en Turiaso (Tarazona) entre el año 14 y 15 (VilLARONGA, págs. 282-283). Presenta la contramarca, cabeza de águila hacia la izq., en el cuello de Tiberio. Corresponde a la $\mathrm{n}$. XXVIII de Guadan (GuADAN, A. M. DE, "Tipologia de las contramarcas en la numismática ibero-romana», $N H, I X, 17,1960$, págs. 7122).

4. As de Claudio ! acuñado entre los años 41-50 (The Roman Imperial Coinage I, 1984, pág. 127, n. ${ }^{\circ} 95$. A partir de ahora se citará esta serie por RIC).

5. As de Claudio I.

6. Nummus de Constantino I, acuñado entre el 320-321 (RIC, VII). No se distingue por la fotografía el exergo.

7. Sestercio de Domiciano.

8. Dupondio de Trajano (IMP NERVA TR...).

Hay dos aras procedentes de Cuntis, casi idénticas, dedicadas a las Ninfas, que aparecieron junto a las fuentes termales de Forniños ${ }^{17}$.

que den la información, a los Médicos Directores de Baños, Reseña de los Principales Balnearios de España. Madrid, 1903 que citaremos por M.D.B.

${ }_{16}$ Garcia Romero, C., "Cuntis. Memorias romanas", BRAG, XII, La Coruña, 1922, págs. 174-180; Garcia Alen, A., La Moneda Hispánica en el Museo de Pontevedra, pág. 115, n. 3 y pág. 138, nota 32; y Filgueira Valverde, J. y García Alen, A., "Materiales para la Carta Arqueológica Provincial de Pontevedra", MP, VIII, 1954-56, pág. 175.

${ }_{17}$ MorA, G., «Las termas romanas en Hispania», AEA 54, 1981, pág. 52; Diez DE VELASCO, $F$. de $P$., "Balnearios y dioses de las aguas termales en Galicia romana", $A E A 58,1985$ págs. 85-86; y Garcia Fernández-Albalat, B., op. cit., 158, 16.G.a. y 16.G.b. 


\section{NYMP/HIS C A/NTONIVS / FLORVS \\ NYMP/HIS C /ANTONIVS / FLORVS}

(C.I.L. II, 2546; VIVES, J., Inscripciones latinas de la España romana. Barcelona 1971, n. ${ }^{\circ} 603$, se citará a partir de aquí por VIVEs).

2. Orilla del río Deva o próximo al Balneario de la Hermida (Potes, Santander). Las aguas del balneario son clorurado-sódicas y sus dos fuentes están a un temperatura de $52^{\circ}$ a $61^{\circ} \mathrm{C}$.

En los primeros días de septiembre de 1910 unos obreros que trabajaban en la carretera de La Hermida a Potes se encontraron, a unos doscientos metros de distancia del puente que une la carretera con el balneario, un depósito compuesto por quince monedas de oro y dos hebillas de bronce. Estaban «entre los escombros de piedra caliza desmenuzada y revuelta con tierras arcillosas que caen de grandes alturas en tiempo de lluvias y nieve» ${ }^{18}$.

Podemos decir que el lugar del hallazgo es una garganta muy estrecha entre dos farallones. Pérez Galdós nos la describió perfectamente: «Llaman a ésto gargantas: debiera llamársele "esófago de La Hermida", porque al pasarlo se siente uno tragado por la tierra. Es un paso estrecho y tortuoso entre dos paredes, cuya alta cima no alcanza a percibir la vista. El camino como el río, va por una gigantesca hendidura de los montes resquebrajados» ${ }^{19}$. Es además una zona en la que se encuentran vestigios romanos ${ }^{20}$. Presentamos este hallazgo porque, aunque podría tratarse de un ocultamiento debido a muy diversas causas incluidas las militares, sin embargo, por el lugar en que ha aparecido podria tratarse de una ofrenda a la divinidad de la fuente termal o al río Deva. Este topónimo celta es bastante frecuente y viene a corresponder con el nombre latino diva o dea, «diosa», que se daba a rios divinizados ${ }^{21}$. Todas las monedas

18 Todo to que sabemos sobre este hallazgo se lo debemos a Jusué, Eduardo, “Monedas de oro de la época visigótica halladas en la provincia de Santander», BRAH, LVII, 1910, págs. 482-487. Resumido su artículo, fue publicado por MATEU Y Llopis, F., "Hallazgos monetarios (III)», Ampurias, VI, 1944, pág. 228, n. ${ }^{\circ}$ LXXXVII

${ }^{19}$ Cuarenta leguas por Cantabria.

20 Tenemos el término Flevenia, la lauda votiva o sepulcral con decoración geométrica que se ha colocado como frontal del altar mayor y las vías romanas que atraviesan los Picos de Europa. Para comprender la situación geográfica y características del balneario se pueden consultar las obras de PIDAL, P. (Marqués de Villaviciosa de Asturias) y ZABALA, J. F., Picos de Europa, contribución a las Montañas Españolas. Madrid 1918, págs. 49-51, 97 y 113; Enriquez de Salamanca, C., Por los Picos de Europa (de ándara al cornión). Las Rozas de Madrid 1985, págs. 55-62, incluye una fotografía de La Hermida en la última página.

21 Kretschmer demostró en su día (Melanges Pedersen. Copenhague 1937, pág. 77) que el topónimo Deva en ríos y ciudades es céltico; Moralejo Lasso. A., Toponimia gallega y leonesa. Santiago de Compostela 1977, pág. 27, nota 12 y 31, nota 23. 
y los objetos se desperdigaron. Xavier Barral i Altet ha revisado el estudio de Jusué y trató de localizar la moneda que el Ingeniero de Minas, Sr. Garnica, regaló al Museo Municipal de Santander, siendo su búsqueda infructuosa tanto en este Museo como en el Museo Provincial de Prehistoria y Arqueología ${ }^{22}$. Para BARRAL i Altet, a quien seguiremos en la clasificación, se encuadraría cronológicamente este conjunto entre los años 576-577.

1. Tremissis de Justino $\|^{23}$.

2. Tremissis de Justino II (MILES, G.C., The Coinage of the Visigoths of Spain Leovigild to Achila II, H.S.S. 2. New York 1952, pág. $\left.181, \mathrm{n} .^{\circ} \mathrm{c}\right)$

3. Tremissis de Leovigildo (HEISS, lám. I, 1; MILES, op. cit., n. ${ }^{\circ}$, d) ${ }^{24}$.

4. Tremissis de Leovigildo ${ }^{25}$.

3. Balnearios de Ontaneda y Alceda (Villacarriedo, Santander). Sus aguas son sulfurado-cálcicas y tienen una temperatura de $25^{\circ} \mathrm{C}$.

En una cita el Sr. García Lomas nos dice: «los romanos calmaron sus dolencias con las (aguas) termales, a juzgar por las monedas encontradas en los manantiales de Alceda, y de la Hermida y otros de la Montaña" ${ }^{26}$. Como desconociamos en donde pudo recoger esta noticia, intentamos confirmarla preguntándoselo a los actuales dueños del balneario, quienes manifestaron que desde 1901 en que su familia venia siendo propietaria del mismo no habían encontrado en él ninguna moneda, ni tenía noticias de que en épocas anteriores hubiesen aparecido. Sin embargo, una indicación de Díaz de Velasco nos puso sobre la pista de la obra de

${ }^{22}$ Barral i Altet, X., «A propósito de un tesoro de monedas visigodas hallado en La Hermida (Santander) en 1910", Numisma, XXVI, n. ${ }^{\circ} 138-143$, 1976, págs. 219-223; y en La circulation des monnaies suèves et visigotiques, Instituto histórico alemán de París, Beihefte der Francia. 4, Munich 1976, págs. 83-86, lám. IV.

23 Corresponde a los $n .^{\circ} 1$ y 2 de MATEu y Llopis.

${ }^{24}$ Este fue el regalado por el Sr. Garnica a! Museo Municipal de Santander.

${ }^{25}$ Este fue el que mostró el Sr. Garnica a Jusué quien lo presentó a la Real Academia de la Historia.

${ }^{26}$ Garcia Lomas, G. Adriano: Mitología y supersticiones de Cantabria. Santander 1964, pág. 251. 
Manuel Ruiz de Salazar y Fernández, Director de los baños de Ontaneda y Alceda ${ }^{27}$, que citará, también, Vega de la Torre ${ }^{28}$.

Al practicar las excavaciones «aparecieron entre las primeras capas gran número de monedas de oro, plata y cobre de las que en la actualidad se hallan en circulación; y después á la profundidad de bastantes piés se hallaron muchas monedas y medallas romanas, unas destruidas y gastadas, y otras en buen estado de conservación, de las cuales se hallan en nuestro poder las que á continuación describiremos".

Nosotros hemos tratado de identificar las seis monedas partiendo de los datos que se nos da.

- Monedas de oro, plata y cobre modernas.

- Monedas y medallas romanas.

1. As de Augusto de la ceca de Caesaraugusta, acuñada entre los años 12 a. C. al 6 a. C. (Villaronga, pág. 262, n. 979 ó 980). Se la cita en $5 .^{\circ}$ lugar.

${ }^{27}$ Ruiz de SalazAR, M., Monografía de los baños y aguas mineromedicinales nitrógenoacidulo-sulfuradas de Ontaneda y Alceda. Madrid 1876, págs. 111-113. Los hallazgos que nos describe deben de estar más cerca de pertenecer al balneario de Alceda que al de Ontaneda, aunque, por los 340 metros de distancia que hay entre uno y otro, da lo mismo, pues el caso está justificado. El hecho es que al formar parte los dos balnearios de la misma Dirección, trata de desempeñarlos, como él dice en la página IX, «con el mismo celo e imparcialidad». Esta circunstancia le lleva a no querer establecer diferencias. Pero la explicación que nos da de por qué aparecen las monedas le descubre y nos orienta: «Como durante algún tiempo ántes de recoger los manantiales se bañaban los concurrentes sobre el nacimiento de los mismos, sucedia con frecuencia que al desnudarse dejaban caer al manantial, involuntariamente, las monedas, que llevaban en sus bolsillos y confundidas con el guijo y arena oscura de su suelo, se deslizaban éstas por entre las piedrecillas ó cascajo, en términos, que si no imposible, al menos era sumamente dificil recobrarlas todas". De los dos manantiales el que más posibilidades tenia para el baño en octubre de 1857, fecha en que se iniciaron las obras, era el de Alceda, pues contaba con «una caseta, que apenas servía para libertar de la intemperie a los que se bañaban". Éste tenía tres piscinas para bañarse a la vez cuatro o cinco personas mayores (págs. 119-120), y en la pág. 132 nos dice «diose principio a dichas obras por el surgimiento del manantial dentro de un gran estanque, que encierra en su fondo todo el nacimiento de aquella caudalosa fuente". Como se puede comprobar habia lugares suficientes donde bañarse y perder, según él, las monedas. En cambio el de Ontaneda, según sus palabras «se hallaba el manantial, malamente y sólo en pequeña parte recogido, dentro de una arqueta de seis pies de longitud, por tres y medio de ancho $y$ cinco de profundidad". Sus condiciones, como vemos, no eran muy adecuadas para bañarse, ya que pasando sus medidas a metros mediría 1,66 $\times 0,97 \times$ $1,39 \mathrm{~m}$. Por todo lo cual pensamos que donde aparecieron fue en el manantial de Alceda aunque pudiera haber aparecido alguna en el de Ontaneda.

${ }^{28}$ VEGA DE LA TORRE, J. R., «Numismática antigua de la Provincia de Santander», Homenaje a Sautuola, III, 1982, págs. 241 y 251. 
2. As de Claudio I del año 41 al 51 (RIC, I, 1984, pág. 128, n.. 97). Se la cita en primer lugar.

3 y 4 . Sestercios de Nerón. Se las cita en $2 .^{\circ}$ y $3 .^{\circ}$ lugar.

5. Bronce de Vespasiano o Domiciano. Se la cita en $4 .^{\circ}$ lugar.

6. Un nummus de Constantino II o Constancio II, acuñado en $\mathrm{Ni}$ comedia o Constantinopla entre los años 330-335. Las dudas están motivadas por la mala descripción que nos ha llegado de ella.

4. Manantial de Peña Cutral, Retortillo (Reinosa, Santander).

En 1957, al efectuar unas obras públicas en el manantial de Peña Cutral, próximo a Retortillo, apareció un número indeterminado de monedas. Vega de la Torre nos transmite la noticia recogida en el apéndice de un diario de las excavaciones realizado por el capataz A. Peña ${ }^{29}$, donde nos dice: «Dia 15 de septiembre de 1956. Primer día de trabajo en la zanja para la traída de aguas... Día 25: hemos llegado a Los Trigales; siguen apareciendo trozos de cerámica y una moneda de bronce en perfecto estado; un obrero da principio a colocar los tubos en el manantial y al efectuar la limpieza para colocar el primer tubo dan en aparecer monedas; se me pasa aviso, se sigue el trabajo y se recogen veintiuna, más otras tantas o más que salen completamente deshechas y no pueden recogerse por estar descompuestas... Día 26: continuamos en Los Trigales; muchas cenizas, muros, dos monedas... Día $28 . .$. aparece una moneda de bronce de las tierras vertidas de la excavación de la carretera; se halla en perfecto estado de conservación... Todos estos hallazgos fueron llevados a Santander...». Vega añade que «en una de las vitrinas de la Sala de luliobriga, del Museo de Prehistoria santanderino, pueden verse monedas en bastante mal estado de conservación y cuyas características me llevan a creer son las mismas halladas en al manantial. Pertenecen a una época que va desde los Julio-Claudios a los Flavios».

- Veintiuna monedas y otras tantas o más completamente deshechas. Pertenecen a una época que va desde los Julio-Claudios a los Flavios.

5. Rio Hijar (Reinosa, Santander).

\footnotetext{
29 Vega de La ToRre, J. R., op. cit., 1982, pág. 253, nota 74
} 
Tenemos una información del hallazgo de un denario en el río Hijar ${ }^{30}$.

- A.l Aparece resellada por los romanos con un busto (y) ... una M.

- R./ Jinete con lanza y debajo del caballo se lee OSAMA (Osma).

La interpretación de estos datos nos lleva a creer que se trata de un denario del siglo । a. C. correspondiente a la ceca de Bolskan, que es, como se ve en la leyenda ibérica del reverso, la que más se podría parecer de todas las leyendas ibéricas a la palabra OSAMA. Como no tenemos más datos no podemos precisar a que grupo, de los que establece Villaronga por su estilo, pertenece.

- En el anverso llevaría detrás de la cabeza * $\mathrm{r}$

- En el reverso a los pies del jinete y sobre una línea: $*$ M

(Villaronga, págs. 168-169, n. ${ }^{\circ} 482$ al 487)

6. Ría de Bilbao.

Se conocen diez monedas recogidas a principios de siglo, durante las labores de dragado, en la barra de la Ría de Bilbao, frente a Portugalete y Las Arenas. Otras tres fueron recogidas en las proximidades de la desembocadura de la Ría. $Y$ hay ocho con posibilidades de tener la misma procedencia que las primeras.

Nos hemos apoyado para dar esta información en los datos y nueva clasificación que nos ofrece Juan José Cepeda ${ }^{31}$.

1. As de la República romana, acuñado en Cerdeña, 209 a. C. (BABELON, E., Description historique et chronologique des monnaies de la République Romaine vulgairement appelées monnaies consulaires. Paris 1886 , vol. I, pág. $238, n .{ }^{\circ} 10$ (variante en CRAWFORD, M. H., Roman Republican Coinage. Cambridge 1974, 65/2).

2. Sestercio de Trajano, acuñado en Roma, 112-114 (RIC, II, n. ${ }^{\circ}$ 624).

3. Sestercio de Trajano, acuñado en Roma, 116-117 (BMC $=$ MATTINGLY, H., Coins of the Roman Empire in the British Museum. Londres III, pág. 223, n. ${ }^{\circ}$ 1046)

${ }^{30}$ Duque Y Merino, D., "Nuevas antigüedades descubiertas en luliobriga", Revista de España, n. ${ }^{\circ}$ 105. Madrid 1885, pág. 526, nota 1 en págs. 526 y 527; y VEGA DE LA TORRE, J. R., «Numismática antigua de la Provincia de Santander», Homenaje a Sautuola, III, 1982, pág. 239.

${ }^{31}$ Cepeda OCAMPo, J. J., Moneda y circulación monetaria en el Pais Vasco durante la antigüedad (Siglos I| a. C.-v d. C.). Bilbao 1990, págs. 32-36. 
4. Dupondio de Adriano, acuñado en Roma, 118 (BMC, III, pág. 404, n. ${ }^{\circ 1139)}$

5. Sestercio de Adriano, acuñado en Roma, 134-138 (BMC, III, pág. 477, n. ${ }^{\circ}$ 1566).

6. Sestercio de Adriano, acuñado en Roma, 134-138 (BMC, III, pág. 469, n. ${ }^{\circ}$ 1507).

7. Sestercio de Adriano, acuñado en Roma, 134-138 (BMC, III, pág. 473, n. $^{\circ} 1536$ ó 1537).

8. Sestercio Diva Faustina I, acuñado en Roma, 141 (BMC IV, pág. 243, n. ${ }^{\circ} 1519$ ó 1520).

9. Sestercio de Faustina II, acuñado en Roma, 147 (BMC, IV, pág. 377, 2168).

10. ¿Bronce? de Faustina II, acuñado en Roma, 161-176.

11. ¿Bronce? de Marco Aurelio, acuñado en Roma, 164-165.

12. Sestercio de Marco Aurelio, acuñado en Roma, 177-178 (BMC, IV, pág. 674, n. ${ }^{\circ}$ 1677).

13. ¿Bronce? de Maximino, acuñado en Roma, 236-237.

Probables:

14. Dupondio de Tito, acuñado en Roma, 72-76.

15. Sestercio de Trajano, acuñado en Roma, 104-111 (BMC, III, pág. 164, n. ${ }^{\circ} 772,775$ ó 777 ).

16. Sestercio de Adriano, acuñado en Roma, 128-132 (BMC, III, pág. 446, n. ${ }^{\circ} 1370$ ).

17. Sestercio de Adriano, acuñado en Roma, 134-138 (BMC, III, pág. 468, n. ${ }^{\circ}$ 1502).

18. Sestercio de Antonino Pío, acuñado en Roma, 138 (BMC, pág. 170, variante de anverso).

19. Sestercio de Diva Faustina I, acuñado en Roma, 141 (BMC IV, pág. 244, n. ${ }^{\circ}$ 1522).

20. Sestercio de Faustina II, acuñado en Roma, 147.

21. Sestercio de Maximino, acuñado en Roma, 236 (BMC, VI, pág. 228, n. ${ }^{\circ} 72$ ).

7. Ria de Plencia (Bilbao, Vizcaya). 
Por información recogida en la prensa del día 7 de junio de 1965 por don Eugenio Uranga y transmitida a Mateu y Llopis ${ }^{32}$, sabemos que apareció una moneda de Nerón en la ría, la $n .^{\circ} 1$. Posteriormente la darian a conocer mejor, junto con otras dos ${ }^{33}$.

1. Sestercio de Nerón, acuñado en Lyon entre el 64-67 (RIC, I, 1984, pág. 174, n. ${ }^{\circ} 390$ ).

2. Sestercio de Adriano, acuñado en Roma entre el 128-138 (BMC, III, 1976 (Reimpresión revisada), pág. 446, n. ${ }^{\circ}$ 1370, lám. 83, 13).

3. Sestercio de Julia Mamea, acuñado en Roma el 228 (BMC, VI, 1962, págs. $160-161$, n. $^{\circ} 487,490$ ó 492).

8. Baños de Fitero (Navarra). Sus aguas son clorurado-sódicas y tienen una temperatura de $48^{\circ} \mathrm{C}$.

Con los datos que contamos hasta ahora resulta difícil determinar que todos los hallazgos monetarios recogidos en este balneario han sido utilizados como ofrendas.

Sabemos por doña M. Ángeles Mezquiriz que recoge lo que nos dejó escrito don Saturnino Mazota ${ }^{34}$, que «Al O del Balneario Viejo, al pie del cerro de su derecha y frente a esa galeria, en 1861 descubrieron restos de un edificio romano, acaso termas y en él trozos de ánforas, barro saguntino y medallas hoy en el Museo de Pamplonà» ${ }^{35}$.

- Monedas.

En el trabajo de Medrano Marqués y Díaz Sanz sobre el único pozo romano que se conserva en Fitero de los catorce que se han hallado, nos presentan un medallón de Marco Aurelio y Cómodo y nos dicen que esta pieza «fue hallada en el término municipal de Fitero en el pasado siglo. Por las referencias que hemos podido obtener, parece que fue encontrada

${ }^{32}$ Mateu y Llopis, F., «Hallazgos monetarios (XX)», NH, XI, 21, 1927, pág. 61, n. 1226.

${ }^{33}$ Nolte, E., «Moneda romana de la Ria de Plencia», Kobie, 9, 1979, 137-138; y «Miscelánea arqueológica», Kobie, 14, 1984, pág. 198.

${ }^{34}$ Mezouiriz lrujo, M. A., "Las termas romanas de Fitero", PV, XLVII, Anejo 3, 1986, pág. 542; y Mazota y VICENTE, S., Notas hidrológicas y clínicas de los balnearios de Fitero, Zaragoza, Imprenta Berdejo, 1930, pág. 4.

35 Entiéndase por barro saguntino y medallas que se está refiriendo a cerámica sigillata y a monedas, como se llamaban entonces. Sobre la posible identificación de estas monedas en el Museo de Navarra tenemos que pensar que si la actual Directora del mismo, doña M. Ángeles Mezquiriz no las citó en su trabajo es porque en la actualidad no se pueden identificar entre las existentes en el monetario del Museo. 
en o cerca de las instalaciones balnearias" ${ }^{36}$. Como vemos, son unas afirmaciones muy débiles para pensar que en algún momento pudo servir de ofrenda. No obstante, nos queda la duda de si pudo aparecer en la excavación de alguno de los pozos o cisterna anteriormente señalados y descubiertos en 1861. Sus datos, aunque no le podamos admitir como ofenda, son:

- Medallón en bronce de Marco Aurelio y Cómodo (GNecchl, F., Medaglioni romani, vol. II, Reimpresión anastática de la edición de Milán, 1912, pág. 44, n. ${ }^{\circ} 6$, lám. 71, n. $^{\circ} 9$ (por defecto de la edición se ve en negativo).

9. Balneario de Panticosa (Huesca). Dispone de seis manantiales de aguas nitrogenadas y sulfurado-sulfhidricas. Cuenta con una temperatura media de $26^{\circ}$ a $29^{\circ}, 5 \mathrm{C}$.

La primera fue encontrada en las proximidades del «Manantial del Estómago", por el Ingeniero de Minas, don Juan Manuel López de Azcona, en $1951^{37}$.

1. As de Augusto correspondiente a la ceca de Caesaraugusta del año 8 a. C. (Villaronga, pág. 262, n. ${ }^{\circ} 980$ ).

Cuatro monedas hispanorromanas recogidas al descubrir el nacimiento del pozo designado modernamente como «Fuente de Tiberio" ${ }^{38}$. Con ciertas reservas se pueden identificar como:

2. As de Sagunto, 1. ${ }^{\text {a }}$ mitad del siglo । d. C. (VILlaronga, pág. 227, n. ${ }^{\circ}$ 822; Vives y Escudero, A., La moneda Hispánica. Madrid 1926, lám. XVIII, n. ${ }^{\circ} 2$ ó 3)

3. As, pequeño módulo, de Tiberio correspondiente a la ceca de Celsa, entre los años 19 al 37 (VILlaronga, pág. 282, n. ${ }^{\circ}$ 1077).

4. Semis frustro.

5. Cuadrans frustro.

\footnotetext{
${ }^{36}$ Medrano Marqués, M. M. y Díaz Sanz, M. A., «Las instalaciones balnearias romanas de Fitero", PV, (I C.G.H.N., 2. ${ }^{\circ}$ vol.), 1986, págs. 491-501. Sobre el mismo pozo se puede ver el trabajo de Mezouiriz lrujo, M., op. cit., PV, XLVII, Anejo 3, 1986, págs. 539-554, con planos y dibujos.

${ }^{37}$ Beltrán, A., «Moneda romana de Zaragoza, hallada en Panticosa», Caesaraugusta, 4, 1954, págs. 139-140; Mateu Y LlopIS, F., «Hallazgos monetarios (XII)», NH, IV, 7, pág. 125, n. 740.

${ }^{38}$ Beltrán, A., "Los hallazgos del balneario de Panticosa (Huesca)», Caesaraugusta, 5 , 1954, págs. 196-200; BELTRÁN, “PANTICOSA (Huesca)», NAH, III-IV, 1954-55, pág. 311, n. ${ }^{\circ} 1067$; y Mateu Y Llopis, F., «Hallazgos monetarios Xll», NH, IV , 7, 1955, pág. 125, n. ${ }^{\circ} 740$.
} 
10. Balneario de Caldas de Malavella (Gerona). Sus aguas son bicarbonatado-sódicas con una temperatura de $50^{\circ}$ a $60^{\circ} \mathrm{C}$.

Se han recogido monedas en los dos manantiales termales que se encuentran distantes uno del otro un centenar de metros. En el primero se descubrieron, en las excavaciones realizadas, restos de animales del cuaternario, sílex trabajados, cuchillos y puntas de flecha correspondientes a la «edad de piedra pulimentada» y una piscina de época romana en la que al vaciar la tierra aparecieron monedas y cerámica sigillata ${ }^{39}$.

1. Monedas romanas.

Del segundo, "Puig de Sant Grau», conocemos que «al vaciarse la piscina mayor se excavó un yacimiento de más de dos metros de grueso, en el cual aparecieron, juntamente con materiales modernos y otros antiguos sin importancia", muchas monedas de las que conocemos ${ }^{40}$ :

2. As de Ampurias con leyenda ibérica del siglo ॥ a. C.

3. (otra igual)

Muchas monedas imperiales. Las que se citan son:

4. Antonia, mujer de Druso (45-54)

5. Sabina.

6. Adriano.

7. Antonino Pío.

8. Gordiano III.

9. Constancio 11.

y otras («Otras muchas inclasificables, por estar fuertemente alteradas por la acción del agua mineral»).

Entre la cerámica había dos fragmentos con sellos de OF MIN y ZOILI, ésta última dentro del dibujo de la planta de un pie.

En 1871 se encontró un ara dedicada a APOLLINI AVG ${ }^{41}$.

APOLLINI / AVG. HO/NORI MEM/ORIAEQUE L. / AEMILI L. FIL. QVIR(ina) CELATI/ANI PORCIA / FESTA FILI / KARISSIMI / L. D. D. D. (C.I.L. II Supl. 6181)

${ }^{39}$ Guía oficial de los establecimientos balnearios y aguas medicinales de España (R.O. de 28 agosto, 1926), año 1927, ed. Rudolf Mosse, págs. 289-290; y Serra Rafols, J. de C., “Las termas romanas de Caldas de Malavella (Gerona)», AEA, XIV, 1941, pág. 307.

40 Serra Rafols, J. de C., op. cit., aEA, XIV, 1941, pág. 314.

4t Serra Rafols, J. de C., op. cit., pág. 306, nota 1. 
11. Balneario de Caldas de Montbuy (Granollers, Barcelona). Sus aguas son clorurado sódicas con variedad bicarbonatada. Tienen una temperatura de $50^{\circ}$ a $70^{\circ} \mathrm{C}$.

Se conocen varios hallazgos de monedas, sin embargo, resulta difícil precisar, para poder considerarlas como ofrendas, si todas ellas fueron recogidas dentro de las aguas del balneario. Por otro lado, los yacimientos próximos de «Torre Roja» y «Les Cremades», que nos cita el Sr. SALA ${ }^{42}$, dificilmente pueden aportar monedas con una cronología tan alta como las de Constantino I y Honorio, teniendo en cuenta los estudios realizados por MONTES y SALA ${ }^{43}$. Por eso, habría que decir que al menos dos de ellas podrian proceder de las excavaciones que se realizaron dentro de las termas, pues las fechas coinciden en estos últimos autores ${ }^{44}$. SERRA RAFOLS no aclara nada en sus Informes pues no cita ninguna ${ }^{45}$.

1. Follis de Constantino I entre los años $307-313 .{ }^{46}$.

2. As semiuncial del 89 a. C. al siglo । d. C., muy recubierto de concreciones y unido a la siguiente moneda por las mismas.

3. Pequeño bronce frustro ${ }^{47}$.

4. As ibérico de Bolskan correspondiente al siglo I a. C. (VILLARONGA, pág. 169, n. $\left.{ }^{\circ} 488-490\right)^{48}$.

5. Sólido de Honorio acuñado en Rávena entre el 403 - 408 (CARson, R. A. G., Principal Coins of the Romans, vol. III, «The Dominate, AD 294-498». Londres 1981, pág. 88, n. ${ }^{\circ}$ 1572) ${ }^{49}$.

42 Sala Sala, L., «jFue la ciudad de Eusti la antecesora de Caldas de Montbuy? Montbuy, XXIII, n. ${ }^{\circ} 1126$, (Fiesta Mayor, Sábado, 1 de octubre) 1966, págs. s/n.

${ }_{43}$ Montes, A. de y SALA, L., "Elementos para la carta arqueológica del Valle Medio de la Riera de Caldas de Montbuy (Barcelona)», V'll CNA (Barcelona 1960). Zaragoza 1962, págs. 103-105.

${ }^{44}$ Pág. 105

45 Serra Rafols, «Informes y Memorias», n. ${ }^{\circ} 32,1956$, págs. 103-105.

${ }^{46}$ Referencia del Sr. Estrada Garriga de Granollers, tomada en 1951, según MaTEU Y LLOPIS, F., «Hallazgos monetarios», $N H, 1,1953$, pág. 247, n. ${ }^{\circ} 552$.

${ }^{47}$ Las $n .{ }^{\circ} 2$ y n. 3 fueron encontradas en las excavaciones de las termas en 1955 por don M. Ribas, según Mateu Y Llopis, F., "Hallazgos monetarios (XIII)", NH, IV, 8, 1955, pág. $320, n^{\circ} 826$.

${ }^{48}$ Esta noticia fue comunicada por el profesor de la Universidad de Barcelona, don Salvador LLobet, de Granollers en abril de 1971 a MATEU Y LLOPIS, F., «Hallazgos monetarios (XXI)", Numisma, XXI, n. ${ }^{\circ} 108-113,1971$, pág. 192, n. 1307.

${ }^{49}$ Visto en el verano de 1967, MATEU Y LLOPIS, F., "Hallazgos monetarios (XXI)", Numisma, XXI, n. ${ }^{\circ} 108-113,1971$, pág. 193, n. ${ }^{\circ} 1308$. 
6. As correspondiente a Augusto y Agripa de la colonia Nemausus (Nimes), acuñado entre el 20 a. C. al 14 d. C. (RIC, I, pág. 51$\left.52, n .{ }^{\circ} 154-161\right)^{50}$.

Aras votivas dedicadas a APOLLINI aparecidas en las inmediaciones ${ }^{51}$ :

APOLLINI / M. FONTEIVS / NOVANIA(anus) / CONSVLT (o)

(C.I.L. II, 4487)

APOLLINI / L. MINICIVS / APRONIANVS / GAL. TARRAC / T.P.I.

(C.I.L. II, 4488)

APOLLINI / SANCTO / L. VIBIVS / ALCINOVS

(C.I.L. II, 4489)

Q. CASSIVS / GARONICVS / A(pollini) V.S.L.M.

(C.I.L. II, 4490)

12. Aguas termales de la Font de N'Horta (Torre de l'Espanyol, Tarragona). Sabemos que brota un agua cálida, pero ignoramos su temperatura.

Al limpiar la balsa de la fuente que mide $11,30 \times 10,50 \times 4 \mathrm{~m}$, se recogieron varios materiales arqueológicos de los cuales sólo se ha conservado una parte. Treinta y una monedas, una punta de bronce, un fragmento de una placa de bronce, una laminita de oro y trozos de cerámica ${ }^{52}$.

1. As de la ceca de llercavonia, acuñada en el siglo । a. C., anterior al año 27 a. C. (Dertosa, Tortosa, Tarragona) (VILLARONGA, pág. 250, n. ${ }^{\circ} 939$; VIVEs, lám. CXXV, 1)

2. Cuadrans de la ceca de llercavonia (Dertosa, Tortosa, Tarragona).

3. As de Augusto de la ceca de Tarragona, posterior al año $2 \mathrm{~d}$. C. (Villaronga, pág. 259, n. ${ }^{\circ}$ 952; Vives, lám. CLXIX, n. ${ }^{\circ} 11$ )

4. As de Augusto, frustro.

\footnotetext{
${ }^{50}$ Fue visto en el verano de 1967 por MATEU Y LLOPIS, F., «Hallazgos monetarios (XXI)", Numisma, XXI, n. ${ }^{\circ}$ 108-113, 1971, pág. 193, n. 1309.

51 Montes, A. de y SaLA, L., op. cit, CNA (Barcelona 1960). Zaragoza 1962, págs. 105-107.

52 Genera, M. y Campos M., "Hallazgos monetarios en la Font de N'Horta (Tarragona)", II Simposi Numismàtic de Barcelona. Barcelona 1980, págs. 203-209.
} 
5. Semis de Tiberio de la ceca de llercavonia (Dertosa, Tortosa Tarragona) acuñado entre el 14 al $37 \mathrm{~d}$. C. (VILlaronga, pág. 282, n. 1075 ; VIVES, lám. CXXV, n. ${ }^{\circ}$ ).

6. As de Tiberio de la ceca de Sagunto acuñado entre el 14 al 37 d. C. (VILlaronga, L., Las monedas de Arse-Saguntum. Barcelona 1967, lám. X, n.o 121).

7. As de Vespasiano acuñado en Roma entre el 74-75 (RIC, II, pág. $81, \mathrm{n}^{\circ}{ }^{\circ}$ 561-a)

8. As de Domiciano, frustro.

9. As de Vespasiano, Tito o Domiciano.

10. As de Adriano acuñado en Roma entre el 119-121 (RIC, II, pág. 412, n. ${ }^{\circ}$ 574)

11. As de Adriano.

12. As de Adriano.

13. As de Antonino Pío acuñado en Roma entre el 145-161 (RIC, III, pág. 130, n. $827-a)$.

14. As de Antonino Pío.

15. As de Antonino Pío.

16. Sestercio de Antonino Pío.

17. As de Marco Aurelio.

18. As de Marco Aurelio.

19. As de Marco Aurelio.

20. Dupondio de Marco Aurelio.

21. As de Faustina II acuñado en Roma entre el año 145-175 (RIC, III, pág. 345, n. ${ }^{\circ}$ 1636)

22. As de Faustina II acuñado en Roma entre el año 145-175 (RIC, III, pág. 345, n. $^{\circ} 1636$ )

23. As de Faustina II acuñado en Roma entre el año 145-175 (RIC, III, pág. 347, n. ${ }^{\circ}$ 1670)

24. As de Marco Aurelio, Lucio Vero o Cómodo.

25. As de Faustina II, Lucila o Crispina.

26. As incierto de los Antoninos.

27. As incierto de los Antoninos.

28. As incierto del Alto Imperio. 
29. Sisens de Luis XIII (BotET Y SIso, J., Les monedes catalanes. Barcelona 1908, vol. III, pág. 121

30. Frustra.

31. Frustra.

13. En el río Boeza, afluente del Sil, a la altura de San Miguel de las Dueñas (León).

Conocemos el hallazgo de dos monedas recogidas por areneros y entregadas al capataz de la explotación quien nos las mostró. Este hallazgo nos recuerda las ofrendas de armas de bronce al Sil, próximo al Boeza, que conocemos por López Cuevillas. Tal circunstancia nos hace sospechar que pudiera tratarse, en este caso, de ofrendas realizadas al rio Boeza. Las incluimos, además, como noticia inédita.

\section{Número 1}

Augusto (12 a. C.) (figs. 3)

A.: De dcha. a izq. AVGVSTVS - DIVI F .

Desc. rev.: Busto laureado a dcha.

R.: II VIR .Q . C.VAR. RVF SEX. IVL. POL

Desc. rev.: Simpulo, aspergillo, segur y apex.

Tipo: As ; ceca: Cartagonova

Peso: 13,70 gr; módulo: $28 \mathrm{~mm}$; grosor: $3 \mathrm{~mm}$; ejes: 10; conserv.: R.

Ref. bibl.: Villaronga, pág. $264, n^{\circ} 992$.

\section{Número 2}

Augusto (2 -14 d. C.) (figs. 4) A.: De dcha. a izq. IMP . AVGVST . PATER. PATRIAE .

Desc. anv.: Busto laureado a dcha.

R.: L. VALENTINO bajo linea a los pies del toro L. NOVO, delante del toro II / VIR, M CAL

Desc. rev.: Toro a dcha.

Tipo: As ; ceca: Calagurris.

Peso: 11,33 gr; módulo: 29,5 mm; grosor: 2,2 mm; ejes: 12; conserv.: R.

Ref. bibl.: VILLARONGa, pág. 262, n. ${ }^{\circ} 977$.

14. Fuente "La Reana» o «Fuentes Tamáricas" (Velilla del Río Carrión, Palencia). Puede que sus aguas sean sulfurosas, pero está fresca y mantiene una temperatura constante. 
Estas tres fuentes que terminan uniéndose en una, tan pronto fluyen como están secas. Esta circunstancia mereció que Plinio se fijase en ellas para indicarnos que servían de augurio (XXXI, 23-24). Florez la identificó en su libro La Cantabria de 1768 y los Sres. García y Bellido y Fernández de Avilés emprendieron unas excavaciones cuyo resultado nos ofrecieron en Fuentes Tamaricas, Velilla del Río Carrión (Palencia) ${ }^{53}$. De esta forma, sabemos que en el estanque alargado con cabecera rectangular y en dirección Este-Oeste, se percibian restauraciones de distintas épocas. La última fue la efectuada por $\mathrm{F}$. Hoz el 10 de agosto de 1935, afectando a alguno de los sillares de contención sobre los que se le asentó el hormigón. Las excavaciones se realizaron en torno al estanque, según se ve en el plano que nos presentan de la figura $1 \mathrm{y}$, como dicen en el informe ${ }^{54}$, no apareció cerámica sigillata ni moneda antigua. Sin embargo, añade que uprocedente del cieno extraido durante estos trabajos (a pesar de haber sido cuidadosamente revisado por nosotros) ${ }^{55}$, nos ha sido entregado por don Guillermo Herrero, en octubre de 1961, un mediano bronce de Augusto, acuñado bajo Tiberio (Cohen 228)", además de un fragmento de piedra $(13 \times 10 \mathrm{cms})$ de una estela hispano- romana y otros de cerámica. También señalan, más adelante, que se recogieron «entre el cieno, una "blanca", de Enrique III y otra, de bronce, de Carlos IV o Fernando VII. Diriase que al efectuarse la limpieza y revestimiento del manantial, acaso en la época de fe y medios que revela la erección de la ermita, se rebañó el fondo primitivo del cauce con lo que de antiguo contuviera, $y$, por ello, todo lo que hoy se encuentra es muy posterior». La ermita recibe en la actualidad el nombre de San Juan de Las Fuentes Divinas.

1. Mediano bronce de Augusto, acuñado bajo Tiberio (Cohen, 228). Creemos que debe corresponderse con el as acuñado en Roma entre el año 22/23 - 30 (RIC, I, 1984, pág. 99, n. ${ }^{\circ} 80$ ).

2. Blanca de Enrique III.

3. Bronce de Carlos IV o Fernando VII.

${ }^{53}$ Garcia y Bellido, A. y Fernández de Avilés, A., Fuentes Tamaricas, Velilla del Río Carrión (Palencia), EAE 29, 1961.

${ }_{54}$ Garcia y Bellido, A. y Fernández de Avilés, A., op. cit, eaE 29, 1961, pág. 39, donde dice: "Como nota negativa importante debemos hacer constar la ausencia total, hasta ahora, de terra sigillata y moneda antigua recogidas en nuestras excavaciones".

${ }^{55}$ Cualquier arqueólogo sabe las dificultades que encierra la recogida de objetos en terrenos de estas caracteristicas, por eso no nos extraña que además de la moneda se les pasasen también otros objetos. 
Se ha encontrado un ara romana, partida por la mitad, y en muy mal estado. Sólo se ve una $\mathrm{S}$ como última letra de la primera línea ${ }^{56}$.

15. Río Pisuerga (Herrera del Pisuerga, Valladolid).

Tenemos conocimiento, por distintas fuentes, que algunas personas de esta población suelen ir al río Pisuerga a recoger monedas, pues se encuentran en abundancia ${ }^{57}$.

Un coleccionista que por motivos profesionales visitó varias veces esta población durante los años setenta, tiene en su colección veintiséis piezas compradas de forma selectiva. La mayoría de las que le presentaron las recogían en el río y las que incorporó a su colección son casi todas hispanorromanas de las cecas de Clunia, Caesaraugusta, Celsa, Bílbilis, Turiaso y Graccurris. Hay dos más que corresponden, una a Galba y otra a Vespasiano, así como tres denarios, uno de los cuales pertenece a Antonino.

Es muy dificil poder afirmar que todas ellas procedan del río, lo que sí está constatado por otras informaciones es que la gente va a buscarlas alli. Sospechamos que algunas de las monedas que están en las vitrinas del Castillo de Ampudia y que figuran como procedentes de Herrera, por su pátina, pudieran tener la misma procedencia. Ahora bien, lo que ocurre es que resulta también difícil justificar si la presencia de monedas en el río Pisuerga obedece a razones votivas o no. Lo que sí es cierto es que han aparecido dos aras votivas dedicadas a las Ninfas en esta población.

- Monedas (siglos I a mediados del II)

Aras:

NYMPHIS / SACRVM / L. C(orn.) S(al.)

NYMP/HIS / SAC. / L.C.S.

(C.I.L. II, 2911, a y b)

16. Caldas das Taipas (Caldelas, Guimarâes, Braga). Tiene aguas sulfuradas, sódicas, bicarbonatadas y fluoradas, muy radioactivas, alcanzando una temperatura de $32^{\circ} \mathrm{C}$.

${ }^{56}$ Garcia y Bellido, A. y Fernández de Avilés, A., op. cit., pág. 10, lám. VI, amb).

${ }^{57}$ Esta opinión ha sido confirmada por algunos de los participantes en esta Mesa Redonda. 
En el actual balneario han aparecido entre las ruinas de antiguos edificios y piscinas de época romana columnas, tuberias de plomo y monedas de Trajano ${ }^{58}$.

- Monedas de Trajano.

Está formado este importante yacimiento termal por un edificio circular de siete metros de diámetro con suelo y paredes de granito de $2,40 \mathrm{~m}$ de altura. Se ponia en comunicación con un estanque. Dispone de varias piscinas y un hipocausto que estaba en comunicación con una de ellas.

Se ha encontrado durante 1949 en S. Joâo da Ponte, junto a la iglesia parroquial, un ara dedicada a las Ninfas que podría estar, posiblemente, relacionada con esta fuente termal ${ }^{59}$.

NYMPHIS / G. SVLP. FES/TVS EX VOTO

(C.I.L. II, 5560)

17. Caldas de Vizela (S. Joâo y S. Miguel das Caldas, Guimarâes, Braga). Sus aguas son sulfuroso-sódicas muy radioactivas. Cuenta con cerca de cincuenta fuentes con diferentes grados de temperatura que va desde los $15^{\circ}$ a los $65^{\circ} \mathrm{C}$., predominando las de temperaturas más elevadas.

En este yacimiento termal se han producido hallazgos arqueológicos desde el siglo XVIII, aunque los de estas fechas fueron destruidos o posteriormente tapados. En Lameira y en Poço Quente se han descubierto piscinas recubiertas de mosaicos atribuidos al siglo $\mathrm{IV} \mathrm{d}$. C., largas canalizaciones, muros, monedas, cerámicas e inscripciones. Las ruinas de los estanques se encuentran en gran número a un lado y otro del río Vizela ${ }^{60}$. Pereira-Caldas entregó a la Sociedade Martins Sarmento, según una carta del 20 de agosto de 1901, un denario de Bolskan que se encontró en las excavaciones realizadas para aumentar el nacimiento del manantial de Caldas de «Visella» (Vizela), a dos metros de profundidad en el «tanque das pipas» ${ }^{61}$.

${ }^{58}$ Aunque no conocemos el lugar exacto donde aparecieron las monedas, nos hemos decidido a incluir la noticia porque pudieron haber aparecido en una de las fuentes de tan importante complejo termal. La información me ha sido facilitada por FRADE, Helena en "As termas medicinais de época romana em Portugal", Actas del /l Congresso Peninsular de Historia Antiga (Coimbra, 18-20, octubre 1990), n. ${ }^{\circ} 10$ (en prensa).

${ }^{59}$ Diez de Velasco, F. de P., op. cit., pág. 87, 11; y Mora, G., op. cit., pág. 52, 61.

${ }^{60}$ Frade, Helena, op. cit, Actas del /l Congresso Peninsular de Historia Antiga (Coimbra, 18-20, octubre 1990), n. ${ }^{\circ} 11$ (en prensa).

${ }_{61}^{61}$ Pereira-Caldas, L., "Carta e offerta á Direcçâo Benemerita da Sociedade Martins Sarmento (Guimarâes)", Rev. Guimarâes XVIII, 1901, págs. 156-161. 
En otra excavación en "Visella» se encontró en el lugar «dos banhos do Morisco», antiguamente de «Poço Quente» un medio bronce de Graccurris ${ }^{62}$.

Número 1

Denario de Bolskan (133-72 A.c.)

A./ Busto barbado a dcha. con torques en el cuello, detrás la marca de valor XVI, * $\mathrm{r}$

R./ Jinete con lanza a dcha., debajo sobre una línea

BOLSKAN con caracteres ibéricos, $ৈ \mathrm{MAN}$

Ref.bibl.: VILLARONGA, L.: op. cit., págs. 169 y 172.

Observ.: Pasó a la Sociedad Martín Sarmiento.

Número 2

As de Tiberio, acuñado en Graccurris del 14 al 32.

A./ TI. CAESAR DIVI AVG F. AVGVSTVS

Descr.: Busto laureado a dcha.

R./ MVNICIP / GRACCVRRIS

Descr.: Toro infulado.

Ref. bibl.: Bellino, A., «Catalogo das moedas romanas, celtiberas e wisigodas pertencentes á Sociedade Martins Sarmento», Rev. Guimarâes XVIII, 1901, págs. 192-193, n. ${ }^{\circ}$ LXXXVI (corrijo el error del número de las páginas de Pereira-Cladas; VILLARONGA, L., op. cit., págs. 285286.

También se han recogido dos inscripciones dedicadas a Bormanicvs y otras dos dedicadas a las Ninfas, fueron localizadas en lugares próximos de Guimarâes y Tagilde ${ }^{63}$.

MEDAM/VS CAMAL.I / BORM.AN.I / CO.V.S.L.M.

(C.I.L. II, 2402 y Supl., pág. 892; VIVES, 768)

... / ... / NIS F...E... / V CENVS VXISAMENSIS / REO BORMA / ... / GLORIA ...T / PRECIPIAS / PUE.O NE / LINAT HUNC / LAPIDEM

(C.I.L. II, 2403*; VIVES, 769)

ANTONIA / RUFINA / VOTO NINP/HIS LVPIA/NIS LIBENS / ANIMO / POSVIT

(C.I.L. II, 6288; VIVES, 696)

VRBAN / PRO CRYSE/DE / NYMPHIS / EX VOTO / POSVI

\footnotetext{
${ }_{62}$ Pereira-Caldas, L., op. cit., Rev. Guimarâes XVIll, 1901, págs. 161-162.

${ }^{63}$ Diez de Velasco, F. de P., op. cit., aEA 58, 1985, pág. 87-89.
} 
(C.I.L. II, 5569; VIVES, 606)

18. Caldas de Moledo (Oliveira, Mesâo Frio, Vila Real). Sus aguas son hiposalinas sulfuradas, carbonatadas sódicas, y radioactivas. El agua de sus fuentes tiene una temperatura de $38^{\circ}, 34,8^{\circ}$ y $18,9^{\circ} \mathrm{C}$.

Botelho nos cuenta que años antes de 1907, en torno a 1901, cuando en Moledo se exploró el lugar "da nascente», junto al río Duero, cuyas termas son bien conocidas, aparecieron gran cantidad de monedas coloniales romanas en muy mal estado al haber sido atacadas por las aguas sulfuradas. Algunas tenian aspecto de esponja. Un conjunto de ellas fueron entregadas a los empleados de la casa de Ferreirinha, quienes las llevaron a Oporto, donde se las enseñaron para vender. En Moledo, vendieron otras muchas a los bañistas. Las que él nos da a conocer formaban parte de una colección que compró en Lamego y que, con toda probabilidad, provenían de éstas al igual que la que le ofreció su buen amigo el Padre Guerra ${ }^{64}$. Éstas son las que ahora se describen.

1. As de Augusto, acuñado en Calagurris, 2 a. C.

A./ IMP CAESAR AVGVSTVS PP

R./ ... - Q... B. FLAVO II VIR

Módulo: $28 \mathrm{~mm}$; Conservación: Anverso bueno y reverso malo. Observaciones: Se la entregó el Padre Adriano Guerra de Moncorvo.

Cita bibl.: Delgado, A., Nuevo método de clasificación de las medallas autónomas de España. Sevilla 1876, tom. III, pág. 60, n. 29 , lám. CVII, 29.

2. As de Augusto, acuñado en Celsa, 23 a. C. a 6 a. C.

A./ AVGVSTVS DIVI.

R./ C.V.I.CEL L.SVRA L.BVCCO $\|$ VIR

Módulo: $29 \mathrm{~mm}$; Conservación: Buena

Observaciones: Estaba en una colección que compró en Lamego.

Cita bibl.: VILlaronga, pág. 260, y n. ${ }^{\circ} 56$ en pág. 16.

3. As de Augusto acuñado en Celsa, 23 a. C. a 6 a. C.

A./ AVGVSTVS DIVI F

R./ ... FEST

Módulo: 27 mm; Conservación: Mala

${ }^{54}$ Bothelo, H., «Numismatica e Archeologia, I. Moedas romanas coloniaes (hispanicas) achadas em Trás-os-Montes e Beira», O Archeologo Português XII, 1907. Lisboa, págs. 2325; y Frade, Helena, op. cit., (Coimbra, 18-20, octubre 1990), n. 17 (en prensa). 
Observaciones: Pertenece a la casa de Ferreirinha de Oporto. Cita bibl.: VILLARONGA, pág.260, n. ${ }^{\circ} 959$.

4. As de Augusto acuñado en Celsa, 23 a. C. a 6 a. C.

A./ AVGVSTVS DIVI F

R./ C... FEST... II VIR

Módulo: $28 \mathrm{~mm}$; Conservación: Regular

Observaciones: Estaba en una colección que compró en Lamego.

Cita bibl.: Villaronga, pág. 260, n. 959.

5. As de Tiberio, acuñado en Clunia, 14 d. C. a 28 d. C.

A./ TI CAESAR AVG F AVGVSTV IMP

R./ CN.POMP. M.ANTO ... RAN IIII VIR CLVNIA

Toro a izq.

Módulo: $27 \mathrm{~mm}$; Conservación: Buena

Cita bibl.: Villaronga, pág. 286, n. 1103.

19. Caldas do Cró (Seixo do Cóa, Sabugal, Guarda). Sus aguas son sulfuroso-sódicas y salen a una temperatura de $22^{\circ} \mathrm{C}$.

En el lugar conocido por el "Banho», cuando se procedía a la captación de aguas se descubrieron veinticinco monedas de «ano 200 da nossa era» ${ }^{65}$.

- Veinticinco monedas del año 200 de nuestra era.

20. Balneario de Retortillo (Baños de Retortillo, Ciudad Rodrigo, Salamanca). Posee un manantial con aguas sulfurado sódicas, sulfhidricas que alcanzan una temperatura constante de $48,5^{\circ} \mathrm{C}$.

Este manantial, según le comunicó por carta el 8 de abril de 1913 don Román Marcos y Sánchez al P. Fidel Fita, se descubrió en el lecho del río Yeltes hacía unos cinco o seis años. Cuando se procedió a aislar el manantial y sacar las aguas a la orilla para abastecer el recién construido balneario, se descubrió un enlosado alrededor del mismo «y debajo de estas losas aparecieron seis monedas de oro, y algunas de cobre», además de un ara votiva romana que han incrustado «en la pared de la fonda y hospedería de los bañistas. Una de las monedas es del emperador Vespasiano, en cuyo reverso campea Neptuno con su tridente» ${ }^{66}$.

\footnotetext{
${ }^{65}$ Frade, Helena: op. cit., (Coimbra, 18-20, octubre 1990), n. 26 (en prensa).

${ }^{66}$ FITA, F., «Nuevas lápidas romanas de Santisteban del Puerto, Berlanga (Badajoz), Ávila y Retortillo (Salamanca)", B.A.A.H., LXII, 1913, págs. 543-545.
} 
Bastantes años después, al confeccionar el Catálogo Monumental de la provincia de Salamanca, Gómez Moreno nos vuelve a referir el hallazgo de este manantial. Nos dice que al bajar el nivel del río, "quedó al descubierto la fuente, brotando como surtidor de una grieta, y en torno piedras de sillería, que fueron de edificio, y monedas romanas» ${ }^{67}$. Más adelante, añade que cuando se procedia a allanar el terreno a su vera, para construir un balneario se encontraron «un pozo artificial, ladrillos, baldosas de medio metro en cuadrado, cascos de finas vasijas, una bella fibula de bronce, más monedas y una estela votiva, por fortuna conservada en la pared del nuevo edificio. Las monedas, todas de bronce y en número de más de veinte, se extraviaron, salvo unas pocas, mal conservadas". Éstas corresponden a los números del 2 al 6 . Las noticias que tenemos no son muy claras, pues las piezas que nos describe al igual que el ara votiva no tenemos conocimiento exacto del lugar en que aparecieron, sin embargo, podriamos entender que corresponde todo ello a las obras que se hicieron cuando se procedió a aislar el manantial ${ }^{68}$.

- Seis monedas de oro.

- Algunas de cobre, entre ellas se conoce:

1. As de Vespasiano (69-70)

Desc. rev.: Neptuno con tridente.

Ref. bibl.: FI/C II, pág. 62, n. $^{\circ} 388$.

2. Dupondio de la ceca lusitana de Ebora acuñada el ¿12 a. C.? (Villaronga, pág. 270, n. 1032 ó 1033)

3. As de la ceca de Turiaso. Puede corresponder a las acuñadas a finales del siglo । a. C. o en la primera mitad del siglo । d. C. (VILlaRonga, págs. 244, 261 y 282).

4. Bronce de Trajano.

5. Bronce de Adriano.

6. Emperatriz del siglo III.

El ara votiva está dedicada a las Aqvis Eletesibvs.

EACCVS / ALBINI F. / AQVIS ELE/TESIBVS / VOTVM / L.A.S. (HAEp, n. ${ }^{\circ} 1315$; VIVES, 655)

\footnotetext{
${ }^{67}$ Gómez Moreno, M., Catálogo Monumental de España, provincia de Salamanca. Valencia 1967, pág. 59.

${ }^{68}$ Maluquer de Motes, J., op. cit. Salamanca 1956, pág. 94, sólo nos añade que «se citan con frecuencia hallazgos de moneda imperial romana en las proximidades del Balneario».
} 
21. Balneario de Ledesma (Vega de Tirados, Ledesma, Salamanca). Tiene aguas sulfurado-sódicas entre $27^{\circ}$ y $52^{\circ} \mathrm{C}$.

Dentro de una de las paredes de la construcción que cubre el manantial de aguas termales, según nos dice Dorado ${ }^{69}$, se encontró una moneda de Cómodo ${ }^{70}$.

- Un bronce de Cómodo.

22. Balneario de Baños de Montemayor (Baños, Cáceres). Sus aguas son sulfurado-sódicas-litínicas con una temperatura de $42^{\circ} \mathrm{C}$.

Por el Sr. Mélida sabemos que se descubrieron en un manantial que estaba oculto "diecinueve monedas de bronce, romanas e imperiales» en 1894 y que se conservaban en la administración del balneario en un cuadro ${ }^{71}$.

Efectivamente, en la memoria quinquenal redactada por Gurucharri en 1916 nos dice que su antecesor, don Benito Crespo, cuenta en su memoria de 1894 que en el mes de marzo de dicho año al tratar de recoger el agua que se escapaba de la fuentecita para beber, se encontraron, no sólo las aras que estudió el Padre Fita ${ }^{72}$, "sino tambien varias monedas antiguas, de las cuales se conservaron en el establecimiento seis que, por lo borrosas, no se pudieron descifrar, y además, por orden de mayor antigüedad, una de Antonia madre de Claudio, dos de nuestro compatriota el gran emperador Trajano, una de su sucesor Adriano, dos de Antonino Pío, cinco de Marco Aurelio, una de Constancio, y otra de Marco Antonio Gordiano Pio» ${ }^{73}$.

Según esta relación las monedas halladas serian:

- 1 de Antonia

- 2 de Trajano

- 1 de Adriano

${ }^{69}$ Dorado, B., Compendio histórico de la ciudad de Salamanca continuada por M. Barco López y R. Girón. Salamanca, 1867.

${ }^{70}$ Gómez Moreno, M., Catálogo Monumental de España, provincia de Salamanca. Valencia 1967, pág. 58.

${ }^{71}$ MeLIDA, J. R., Catálogo Monumental de España, provincia de Cáceres (1914-1916), vol. I, pág. 157, n. ${ }^{\circ} 373$ ). El Sr. Roldán no las cita (Roldan Hervas, J. M., "Las lápidas votivas de Baños de Montemayor», Zephyrus XVI, 1965, págs. 5-37), aunque el Sr. Âlvarez Martínez cree que use valió de las monedas aparecidas en el balneario, entre finales del siglo ! y comienzos del iil después de Cristo", para fechar las aras dedicadas a las ninfas (Álvarez Martinez, J. M., Alange y sus termas romanas. Badajoz 1973, pág. 37).

${ }^{72}$ FITA, P. F., «Excursiones epigráficas», BRAH XXV, págs. 146-165.

${ }_{73}$ Gurucharri Y Echauri, J. Eduardo, Memoria quincenal de las aguas minerales de Baños de Montemayor. Madrid 1916 (mecanografiada), pág. 55 y 56. 
- 2 de Antonino Pio

- 5 de Marco Aurelio

- 1 de Constancio

- 1 de Gordiano Pio

- 6 frustras

Total 19

Puestos en contacto con la dirección del balneario a través del doctor Maraver, pudimos estudiar las diecinueve piezas de bronce que junto con cinco medallas, la sexta no se conserva en su hueco, se siguen encontrando dentro de una vitrina-marco en la administración del balneario ${ }^{74}$.

Como resultado de nuestra visita adelantamos el estudio de las monedas. El orden que seguimos en su presentación corresponde al que tienen en el cuadro.

\section{CATÁLOGO}

Número 1

Antonino Pío (140-144) (figs. 5).

Ley. anv.: anTONI... - AVG PIVS p.p

Descripción: Busto laureado a dcha.

Ley. rev.: VICTOia AVG S C

Descripción: Victoria sobre cuádriga a dcha. tirando de las riendas.

Ceca: Roma

Tipo: As; metal: Ae; peso: 4,32 grs; mód.: 23 mm; gros.: 2 mm; ej.: 12; cons.: MM

Ref. bibliográfica: $R / C$ III, pág. $118, n .^{\circ} 708$.

\section{Número 2}

Juliano II (6, nov., 355 - primavera, 360) (figs. 6).

Ley. anv.: IMP IVLIANVS NOB CAES

Descripción: Busto diademado con paludamento y coraza a dcha.

Ley. rev.: FEL TEMP - REPARATIO

Descripción: Soldado alanceando a un jinete caido sobre su caballo mientras levanta su brazo izq.

Exergo: CSLG; Ceca: Lyon, 2. ${ }^{a}$ of.

\footnotetext{
${ }^{74}$ Agradecemos al Dr. Maraver su mediación ante la administración del Balneario de Montemayor, asi como a su administrador legal don Antonio Sierra por todas las facilidades y generosas atenciones recibidas para el estudio de las monedas.
} 
Tipo: nummus; metal: Ae; peso: 2,68 grs; mód.: $18 \mathrm{~mm}$; gros.: 1,6 mm; ej.: 6; cons.: B.

Ref. bibliográfica: RIC VIII, pág. 191, n. 195.

\section{Nümero 3}

Constancio II (348-350) (figs. 7).

Ley. anv.: dn CONSTAN -...S p f AVG

Descripción: Busto diademado a dcha.

Ley. rev.: ...atio

Descripción: Parece el tipo de la leyenda: Fel temp reparatio, con el emperador en pie mirando a izquierda, sosteniendo con la mano dcha. Fénix sobre globo y con la izq. lábaro, sobre una nave gobernada por la Victoria sentada a su izq.

Ceca: ¿ ?

Tipo: nummus; metal: Ae; peso: 5,01 grs; mód.: $23 \mathrm{~mm}$; gros.: $2 \mathrm{~mm}$; ej.: 12; cons.: MM. Le falta un trocito.

Ref. bibliográfica: Como la de RIC VIII, lám. 16, n. 203.

Número 4

¿Domiciano? (81-96) (figs. 8).

Ley. anv.: ...

Descripción anv.: Busto laureado a dcha.

Rev.: Frustro

Tipo: Sestercio; metal: Ae; peso: 6,81 grs; mód.: $28 \mathrm{~mm}$; gros.: $2 \mathrm{~mm}$; ej.: ¿ ? ; cons.: MM.

Número 5

Marco Aurelio (177-178) (figs. 9).

Ley. anv.: ... L ANTON - INVS AVG ...

Descripción: Busto laureado a dcha.

Ley. rev.: IMP v..., En el campo S - C

Descripción: La Equidad de pie, mirando a dcha. y portando en su mano dcha. extendida una balanza mientras sujeta con su izq. una cornucopia.

Ceca: Roma

Tipo: Sestercio; metal: Ae; peso: 17,46 grs; mód.: $29 \mathrm{~mm}$; gros.: $3 \mathrm{~mm}$; ej.: 6; cons.: R

Ref. bibliográfica: RIC, III, pág. 310, n. 1230.

Número 6

Hispanorromana de Sagunto (1. ${ }^{a}$ mitad del siglo । a. C.) (figs. 10). 
Ley. anv.: ...

Descripción anv.: Cabeza galeada de Roma a dcha.

Ley. rev.: SAGV

Descripción rev.: Proa a dcha., en el campo victoria a la izq. y caduceo a la dcha.

Ceca: Sagunto

Tipo: As; metal: Ae; peso: 8,61 grs; mód.: 28,4 mm; gros.: 1,1 mm; ej.: 12; cons: MM.

Ref. bibliográfica: Villaronga, L., Numismática Antigua de Hispania. Barcelona 1979, pág. 227, n. ${ }^{\circ}$ 822; Álvarez Burgos, F., Las monedas Españolas, vol. 1, "La moneda hispánica desde sus orígenes hasta el siglo v». Madrid 1987, edit. Vico \& Segarra, pág. 234, n. ${ }^{\circ} 1619$.

\section{Número 7}

Antonino Pío (138) (figs. 11).

Ley. anv.:

Descripción: Cabeza desnuda a dcha.

Ley. rev.: ... en el exergo pieTAS y en el campo S - C

Descripción: La Piedad en pie, a la dcha. levantando los brazos delante de un altar.

Ceca: Roma

Tipo: Sestercio; metal: Ae; peso: 18,86 grs; mód.: 29 mm; gros.: 4 mm; ej.: 5; cons.: MM

Ref. bibliográfica: Mattingly, H., Coins of the Roman Empire British Museum, «Nerva to Hadrian», vol. III. Londres 1976, pág. 550, n. 1942.

\section{Número 8}

Frustra. Siglo II (figs. 12).

Descripción anv.: Busto radiado a dcha.

Tipo: Dupondio; metal: Ae; peso: 6,06 grs; mód.: 26 mm; gros.: 1,7 mm; ej.: $¿$ ?; cons.: MM

\section{Número 9}

Marco Aurelio (149-161) (Antonino Pío) (figs. 13).

Ley. anv.: avRELIVS CAE - SAR AVG pii fil

Descripción: Busto a dcha.

Ley. rev.: ... pOt ...

Descripción: Virtud sentada a dcha. sosteniendo lanza con la mano dcha. y parazonio en la izq.

Ceca: Roma 
Tipo: Sestercio; metal: Ae; peso: 18,75 grs; mód:: 32 mm; gros.: 3,6 $\mathrm{mm}$; ej.: 11; cons.: MM

Ref. bibliográfica: como la de R/C III, pág 182, n. 1304.

\section{Número 10}

¿Trajano? (98-117) (figs. 14).

Ley. anv.:

Descripción: Busto laureado a dcha.

Rev:: Frustra

Tipo: Sestercio; metal: Ae; peso: 16,30 grs; mód.: $31 \mathrm{~mm}$; gros.: 3,2 $\mathrm{mm}$; ej.: ¿12?; cons.: MM

Número 11

¿Cómodo? (177-192) (figs. 15).

Descripción anv: Busto laureado a dcha.

Tipo: As; metal: Ae; peso: 18,07 grs; mód.: $28 \mathrm{~mm}$; gros.: $3,3 \mathrm{~mm}$; ej.: 11 ; cons.: $M$

Número 12

Antonia (41-50) (figs. 16).

Ley. anv.: ... IA - AVGVSTA

Descripción: Busto de Antonia a dcha. con vestido y cabeza desnuda.

Ley, rev.: TI CLAVDIV... PM TR P IMP En el campo S - C

Descripción: Claudio I con velo y toga de pie a la izq. sosteniendo con su mano dcha. el simpulo.

Ceca: Roma

Tipo: Dupondio; metal: Ae; peso: 9,92 grs; mód.: 26,8 mm; gros.: 2,7 mm; ej.: 6; cons.: B.

Ref. bibliográfica: $R I C$ I (1984), pág. 127, n. 92.

Número 13

Trajano (112-117) (figs. 17).

Ley. anv.: ... AV. GER ...

Descripción: Busto radiado a dcha.

Ley. rev.:

Descripción: Dacia sentada a izq...

Ceca: Roma

Tipo: Dupondio; metal: Ae; peso: 8,85 grs; mód.: 27,1 mm; gros.: 2,3 mm; ej.: 7; cons.: MM

Ref, bibliográfica: $R / C$ II, págs. 288, n. 623 . 
Número 14

Trajano (103-111) (figs. 18).

Ley. anv.: ...AE TRAIANO AVG GER DA...

Descripción: Busto laureado a dcha.

Ley, rev.: ...P...

Descripción: Concordia sedente a la izq., portando cornucopia en su brazo izq. y patera en la dcha.; altar ante ella. sosteniendo cornucopia con la izq.

Ceca: Roma

Tipo: Sestercio; metal: Ae; peso: 22,16 grs; mód: $33,5 \mathrm{~mm}$; gros.: 3,8 $\mathrm{mm}$; ej.: 6; cons.: MM

Ref. bibliográfica: RIC II, pág. 280, n. 496.

Número 15

Adriano (125-128) (figs. 19).

Ley. anv.: hadriANVS - avgustvs

Descripción: Busto con corona radiada a dcha.

Ley. rev.: ...

Descripción: Annona sentada en trono a la izq., portando espigas?, delante niño presentando una cornucopia.

Ceca: Roma

Tipo: Dupondio; metal: Ae; peso: 10,61 grs; mód:: 25 mm; gros.: 2,8 $\mathrm{mm}$; ej.: 6; cons.: MM

Ref. bibliográfica: RIC II, pág. $426, \mathrm{n}^{\circ} 660$.

Número 16

Domiciano (85) (figs. 20).

Ley. anv.: imp caes...GERM COS XI...

Descripción: Busto radiado a dcha.

Ley. rev.: ... En el campo S - C

Descripción: Fortuna de pie sosteniendo cornucopia en su brazo izq. y portando timón con su mano dcha.

Ceca: Roma

Tipo: Dupondio; metal: Ae; peso: 10,91 grs; mód.: 26,3 mm; gros.: 3 $\mathrm{mm}$; ej.: 6; cons.: $M$

Ref. bibliográfica: RIC II, pág. 191, n. ${ }^{\circ} 293$.

Número 17

Lucio Vero (163-164) (Marco Aurelio) (figs. 21).

Ley. anv.: L VERVS AVG armeNIACVS

Descripción: Busto desnudo a dcha. 
Ley. rev.: ... II c.s ii S - C

Descripción: Victoria avanzando a izq., portando corona en su mano dcha. y palma sobre el hombro izq.

Ceca: Roma

Tipo: As; metal: Ae; peso: 6,70 grs; mód:: $23 \mathrm{~mm}$; gros.: 2,9 mm; ej.: 6; cons.: $\mathrm{M}$

Ref. bibliográfica: RIC III, pág. 323, n. 1392.

Número 18

¿Tiberio o Claudio? (¿14-54?) (figs. 22).

Ley. anv.: ...

Descripción: Busto a la izq.

Frustra

Tipo: As; metal: Ae; peso: 8,39 grs; mód.: 26,8 mm; gros.: 2 mm; ej.: ?; cons.: MM

MEDALLA

Número 19

Medalla religiosa de la Virgen con Niño (probablemente de finales del siglo XVI o principios del siglo XVII) (figs 23).

Ley. anv.: ... - ...NE

Descripción: Virgen con la cabeza vuelta hacia el Niño a su izq., sosteniéndole entre sus brazos; éste la mira y sobre sus cabezas hay una aureola.

Rev.: Ondas en el lado dcho. el resto no se distingue.

Metal: Ae; acuñada; peso: 5,25 grs; mód.: 22,5 mm; gros.: $2 \mathrm{~mm}$; ej.: ¿12?; cons.: MM. Le falta el asa de suspensión.

Ref. bibliográfica: Sobre este tipo de vírgenes ver lo que dice el Padre Naval y Ayerve, F., Arqueología y Bellas Artes, vol. II. Madrid 1922, págs. $42-51$ y 491 .

Observaciones: Teniendo en cuenta, por lo que nos dice Limón Montero, que el manantial donde se recogió estaba oculto en 1697, la medalla tendria una cronología anterior a esta fecha.

Las diecinueve aras votivas aparecieron en las excavaciones realizadas en 1845 y 1894. De ellas, once se conservan expuestas en una estantería dentro del balneario, las ocho restantes las dio por desaparecidas el profesor Roldán, que fue quien las estudio y publicó en 1965. En su conjunto hay dos dedicadas a la diosa Salud y trece probablemente a las Ninfas.

SALVTI / VALERIA / PRIVATA / L A V S 
(ROLDAN, 1)

SALFV / RVFIV / LIBES / VOTS / OLVVS

(ROLDAN, 2)

... MPHI. / FONTANAE / .. VIRIATV / . LI . SPR .. /. V .. RON . OM / NISLIBVOAS

(ROLDAN, 3)

(¿ Fontanae o Nymphis?)... / R M .. / MMIS / V . S / L . M

(ROLDAN, 4)

NYMPHIS / LiK . SYRINA / CHES / V.A.L.S.

(ROLDAN, 5)

NYM/PHIS / .MM. / ..S. / VL..

(ROLDAN, 6)

N.M..IS / .VAR.. / .OSV.. / .....

(ROLDAN, 7)

..MPIS / .....ENSIVM / ....VS / ....NICVS / ..VL

(ROLDAN, 8)

.YMPIS / ..PARENSIVM / ...VS / .....

(ROLDAN, 9)

NYM/PHIS / CAPA.. / PREB.. / ..EVE.. / V.A.L.S.

(C.I.L. II, 883; ROLDAN, n. ${ }^{\circ}$ 10)

IS . A... / VITIA . A / MMIRA / LAMESIS / V.L.A.S.

(C.I.L. II, 885)

SVNVA / REBVRR / NYMPHIS / V.S.L.A.

(C.I.L. II, 886)

NIM / PHIS / CIVCH / P.A.V.

(C.I.L. II, 887)

VB... / CRESIVS / NIMPIS / V.S.L.M.

(C.I.L. II, 888)

NYM / PHIS / V.A.CRO

(C.I.L. II, 889)

23. Río Manzanares (Madrid).

En Madrid don José M. Albareda descubrió en las orillas del río Manzanares en marzo de 1955 un vaso romano conteniendo una moneda. Don Luis Pericot sacó la impronta ${ }^{75}$.

- As bilingüe acuñado en Celsa (Velilla de Ebro, Zaragoza) entre los años 50 - 44 a. C. (VILLARONGA, págs. 229, n. ${ }^{\circ} 832$ ).

${ }^{75}$ Mateu $Y$ Llopis, F., «Hallazgos monetarios (XII)", NH, IV, 7, 1955, pág. 133, n. ${ }^{\circ} 761$. 
24. Monte Real (Monte Real, Leiria). Tiene unas aguas sulfatadas, cálcicas y sulfurosas. Salen a una temperatura de $18,5^{\circ} \mathrm{C}$.

En el lugar denominado Covôes, al realizar obras de exploración durante 1807 en el nacimiento de las fuentes, se encontraron varias monedas, un ara y algunos cipos sin inscripción. Las monedas eran todas de cobre y estaban debajo del ara a $70 \mathrm{~cm}$ de profundidad ${ }^{76}$.

Por orden cronológico las que se conocen son las siguientes:

Número 1

Antonino Pío - Marco Aurelio - Lucio Vero (138-180)

A./ AVRELIVS...

Por el único dato que conocemos de esta moneda, podría corresponder a Antonino Pío, Marco Aurelio o Lucio Vero.

\section{Número 2}

Faustina $i ?(141-175)$

\section{A.I ...INA}

Por esta información podría atribuirse a una de las dos Faustinas, Senior o Junior, aunque nos inclinaríamos más por la segunda.

\section{Número 3}

Severo Alejandro (231-235)

A./ IMP ALEXANDER PIVS AVG

Desc. rev.: Busto con paludamento y coraza.

R./ PROVINDENTIA AVG en el campo $\mathrm{S}-\mathrm{C}$

Desc. rev.: Providencia en pie de frente con cabeza vuelta a izq. sosteniendo dos espigas sobre modio y cornucopia.

Ref. bibl.: RIC IV, Parte 2. ${ }^{a}$, pág. 121, n. ${ }^{\circ} 642-647$.

\section{Número 4}

Filipo II (244-246)

\section{A./ PHILIPPVS CAESAR}

Por esta referencia, probablemente incompleta y no bien tomada, podria corresponder a alguna de las que aparecen en RIC IV, Parte 3. ${ }^{\text {, }}$ pág. 101, de la ceca de Roma.

${ }^{76}$ Heleno, Manuel, «ll. Antiguidades lusitano-romanas», O Archeologo XXV, 1922, págs. 8-15. Se encuentra recogida toda la bibliografia que hay sobre este balneario en FRADE, Helena, op. cit., (Coimbra, 18-20, octubre 1990), n. 30 (en prensa). 
Han aparecido varias aras votivas, una de ellas dedicada a Fontana y las otras sin inscripción.

F. S. /FRONT.I /NIVS A/VITVS / A.L.

(C.I.L. II, 337; VIVES, 454)

Aras $i$ ?

25. Cabeço de Vide (Fronteira, Portalegre). Vierte unas aguas sulfurado sódicas, muy radioactivas. Sus tres fuentes alcanzan temperaturas entre $\operatorname{los} 19,7^{\circ}$ y los $20,8^{\circ} \mathrm{C}$.

Cuando se procedía a la construcción del balneario, en 1819, se descubrieron restos de caños, acueductos, estanques de mármol y monedas ${ }^{77}$.

- Monedas.

Junto a la iglesia de Sta. María, en la localidad de Monforte a $18 \mathrm{~km}$ de estas fuentes termales, se ha encontrado una inscripción dedicada a las Ninfas.

LAG. / NYMPHIS / EX VO/TO

(C.I.L. II, 168; VIVES, 617)

26. Charca de Santa Ana (Trujillo, Cáceres).

Al desecarse la mencionada charca se encontró un denario.

- Denario de una de las ramas de la familia Sempronia, la de Lucio Sempronius Pitio del 148 a. C. (BABELón, E., Description historique et chronologique des monnaies de la République Romaine vulgairement appelées monnaies consulaires. Paris 1886, pág. 430) ${ }^{78}$.

27. Lago de Proserpina (Mérida, Badajoz).

Me han llegado noticias de que piragüistas, en concreto uno de Madrid, han recogido alguna moneda en la orilla de la presa de «La Albuera», "Carija», "La charca de Pacheco» o «lago de Proserpina», según los nombres por los que se la conoce ${ }^{79}$. Es posible que este dato coincida con las ofrendas, que según Julio Obsecuente, se hacian ante hechos ex-

\footnotetext{
77 Frade, Helena, op. cit., (Coimbra, 18-20, octubre 1990), n. ${ }^{\circ} 36$ (en prensa).

${ }^{78}$ RAMON Y FeRnÁndez, J., «De numismática extremeña», BSAAV, XV, pág. 79, lám. I, n. ${ }^{\circ}$; y Mateu Y Llopis, F., «Hallazgos monetarios (VI)», Ampurias, XIII, 1951, pág. 242, n. 481.

${ }^{79}$ En la actualidad se está procediendo a la limpieza del lago, esperamos que se examinen los lodos con detenimiento para poder desvelar si recibió este tipo de ofrendas en su seno. Don José M. Álvarez, Director del Museo Nacional de Arte Romano en Mérida, nos ha manifestado que se tendrá en cuenta.
} 
traordinarios a Ceres y Proserpina, stips Cereris et Proserpinae (ver la nota 12).

\section{- Monedas.}

El hallazgo en sus proximidades de la conocida lápida rota, con una inscripción incompleta en la que un particular dirige una devotio y una execratio a Proserpina, diosa de los Infiernos, lleva a pensar que se entendía por los del lugar que este lago era la entrada al Averno ${ }^{80}$. Por ésto, por lo que nos dice Julio Obsecuente y por el pasaje de Valerio Máximo (II, 4, 5), entendemos que esta divinidad guardaba relación con las aguas, de ahi la inclusión de esta noticia.

DEA . ATAECINA TVRi / BRIG. PROSERPIN A / PERTVAM MAIES TATEM / TE ROGO ORO OBSECRO / VTIVINDICES QVOT MIHI / FVRTi FACTVM EST QVISQVIS / MIHI IMVDAVIT INVOLAVIT / MINVSVE FECIT EAS... QI.S.S / TVNICAS. VI ... AENVLA / LINTEA. II. IN. - . IVM.CV / IVS.I.C. ... M.IGNORO /I ... IVS /

\section{Fuente «El Sarso», (El Pla, Crevillente, Alicante).}

Muchos años antes de 1949, según referencia de don J. Lledó Sánchez, se hallaron a seis metros de profundidad, al explotar un barreno en una cantera que está junto a la fuente, veintidós denarios romanorrepublicanos e ibéricos más un cuchillo de «piedra» (¿sílex?) que cortaba magníficamente. El Sr. Mateu nos dice que el Sr. Lledó amablemente le facilitó «la relación de seis piezas conservadas en su poder», aunque luego sólo están citadas cinco ${ }^{81}$. Incluimos este depósito, aunque estaba fuera del agua, por su proximidad a una fuente. El que haya aparecido un cuchillo de piedra nos hace pensar que pudiera haber formado parte de un ritual $y$, en este caso, podría ser considerado todo el conjunto como ofrenda.

1. Denario de L. Thorius Balbus del 105 a. C. (BAbelón, II, pág. 488)

2. Denario de P. Cornelius Lentulus Marcelinus del 100 a. C. (BABELÓN, I, pág. 401, n. ${ }^{\circ}$ 25)

3. Denario Cn. Cornelius Blasio del 112-111 a. C.

4. Denario de Marcus Sergius Silus del 116-115 a. C. (BAbelón, II, pág. 442)

${ }^{80}$ Álvarez Saénz de Buruaga, J., "El hallazgo de la lápida de Proserpina de Mérida», Rev. Estudios Extremeños 11, 1955, págs. 325-337.

${ }^{81}$ Mateu y LlopIS, F., «Hailazgos monetarios», Ampurias, XIII, 1951, pág. 227, n. ${ }^{\circ} 350$. 
5. Denario ibérico de la ceca de Ikalkusken (próximo a Cuenca) acuñada durante el siglo II-I a. C. (VIVES, ceca 90; ViLLARONGA, pág. 139, n. ${ }^{\circ} 328-329$ )

29. Balneario de Fortuna (Murcia). Cuenta con aguas clorurado-sódicas que alcanzan una temperatura de $52,5^{\circ} \mathrm{C}$.

Por los años cincuenta se encontró un depósito compuesto por treinta y un denarios romanos de época republicana en «un paraje cercano» al balneario. De ellos solamente conocemos once ${ }^{82}$. Cronológicamente corresponderia al final del primer cuarto del siglo । a. C.

1. Denario de C. P. Cato (Crawford, Roman Republican Coinage. Cambridge 1974, se citará por RRC, pág. 294, n. ${ }^{\circ} 274$, 1, año 123 a. C. O segun Sydenham, The Coinage of the Roman Republic. Londres 1952, se citará por CRR, pág. 48, n. ${ }^{\circ} 417$, año 137-134 a. C.).

2. Denario de M. F. Philus (RRC, pág. 297, n. ${ }^{\circ} 281$, 1, lám. XXXIX, del año 119 a. C. o CRR, pág. 67, n. ${ }^{\circ} 529$, del año 110-108 a. C.).

3. Denario de Q. Titius (RRC, pág. 344, n. ${ }^{\circ} 341,1$, XLIV del año 90 a. C. o CRR, pá.g. 107, n. ${ }^{\circ} 691$, lám. 20, del año 88 a. C.).

4. Denario de C. V. Pansa (RRC, pág. $347, n .^{\circ} 342,5$ b, lám XLIV, del año 90 a. C. o CRR, pág. 105 , n. ${ }^{\circ} 684$, lám. 20, del año 89-88 a. C.).

5. Denario de Cn. C. Lent. Clod. (RRC, pág. 356, n. $^{\circ} 345$, 1, lám. XLV, año 88 a. C. o CRR, pág. 109, n. ${ }^{\circ} 702$, año 87 a. C.).

6. Denario de Cn. C. Lent. Clod. (RRC, pág. 356, n. ${ }^{\circ} 345$, 1, lám. XLV, año 88 a. C. o CRR, pág. 109 , n. ${ }^{\circ} 702$, año 87 a. C.).

7. Denario de Cn. C. Lent. Clod. (RRC, pág. 356, n. $^{\circ} 345$, 1, lám. XLV, año 88 a. C. o CRR, pág. 109, n. ${ }^{\circ} 702$, año 87 a. C.).

8. Denario de C. M. Censorinus (RRC, pág. $357, n{ }^{\circ} 346,2$ b, lám. $\mathrm{XLV}$, del año 88 a. C. o CRR, pág. 111, n. ${ }^{\circ} 714$, del año 86 a. C.).

9. Denario de P. Crepusius (RRC, pág. 375, n. ${ }^{\circ} 361,1$ a-1 c, lám. XLVII, del año 82 a C. o CRR, pág. 118, n. ${ }^{\circ} 738$, lám. 21, del año 82-81 a. C.).

${ }^{82}$ Agradezco a Manuel Amante esta información que me facilitó en la Mesa Redonda, Amante Sánchez, M. y Lechuga Galindo, M., "Un nuevo hallazgo de denarios romano-repubiicanos en la provincia de Murcia», Numisma, XXXII, n. ${ }^{\circ}$ 177-179, 1982, págs. 9-20. 
10. Denario de C. M. Limetanus (RRC, pág. $374, \mathrm{n}^{\circ} 360,1$ b, lám. XLVII, del año 82 a. C. o CRR, pág. 117, n. ${ }^{\circ} 736$, a, lám. 21, del año 82-81 a. C.).

11. Denario de $P$. Satrienus (RRC, pág. $403, n .^{\circ} 388,1$ b, lám. XLIX, del año 77 a. C. o CRR, pág. 188, n. ${ }^{\circ} 781$, a, lám. 22, del año $75-$ 74 a. C.).

Sobre el culto en el Balneario de Fortuna, remito a la comunicación presentada en esta Mesa Redonda: «El Balneario de Fortuna (Murcia) y la Cueva Negra», por Antonino González Blanco y Manuel Amante Sánchez.

30. Balneario de Caldas de Monchique (Distrito de Faro, Portugal). Sus cuatro fuentes disponen de aguas hiposalinas, bicarbonatadas sódicas y sulfuradas, teniendo una temperatura de $32^{\circ} \mathrm{C}$.

Son numerosas las referencias que existen de hallazgos de monedas y restos de construcción por los alrededores y en las Caldas de Monchique. El que fue médico del balneario, Dr. Augusto da Silva Carvalho, es el que nos da noticias más puntuales al decirnos que en las Caldas y en los alrededores de la villa se han encontrado monedas de oro, plata y cobre. Dos de oro de Honorio, pertenecientes entonces, a don Manuel de Sousa Costa y a don José da Silva Júnior. Las que aparecieron en las termas corresponden a Constantino I, Graciano, Teodosio I, y Arcadio ${ }^{83}$. Los dos sólidos de Honorio no parece que fuesen encontrados en las termas. Las restantes aparecieron en una de las reconstrucciones llevadas a efecto en tiempos del Dr. Silva. En la última demolición, el Director médico del balneario, Dr. José de Sousa Costa, recogió todos los objetos que habian ido apareciendo. Luego los Sres. Formosinho, Da Veiga y Viana nos darían a conocer los de época romana ${ }^{84}$, entre ellos figura una relación de las monedas: «un gran bronce, cinco médios e onze pequenos, desde o Séc. I ao IV, achando-se representados Trajano, Octavio, Cláudio, Máximo, Filipe, Honorio, Graciano, Arcádio e outros». Aunque la fotografia que nos da de las mismas es mala, nosotros hemos tratado por ella de identificar todas las más posibles. No obstante, desconocemos cuales pudieron aparecer en el interior de las fuentes.

\footnotetext{
83 Silva Carvalho, A. da, Memòrias das Caldas de Monchique. Lisboa 1906, págs. 14.

${ }^{84}$ Formosinho, J.; Veiga Ferreira, O. da; y Viana, A., «Estudos arqueológicos nas Caldas de Monchique», Trabalhos de Antropologia e Etnologia, XIV, fasc. 1-4. Oporto 1953-54, págs. 205-211 y lám. XXXIl.
} 
1. Constantino I

2. Graciano

3. Teodosio I

4. Arcadio

5. Nummus de Constancio II. Se corresponde con la $n .^{\circ} 1$ de la lámina XXXII.

6. Nummus de Arcadio. Se corresponde con la n. ${ }^{\circ} 2$ de la lámina XXXII.

7. As de Otacilia Severa, mujer de Filipo I, acuñada entre los años 244-249. Se corresponde con la n. 3 de la lámina XXXII.

8. Imposible identificar. ¿Será la de Honorio? Se corresponde con la n. ${ }^{\circ} 4$ de la lámina XXXII.

9. Nummus de Graciano. Se corresponde con la $n .^{\circ} 5$ de la lámina XXXII.

10. As de Claudio I. Se corresponde con la $n .^{\circ} 6$ de la lámina XXXII.

11. As de Claudio I. Se corresponde con la n. ${ }^{\circ} 7$ de la lámina XXXII.

12. Antoniniano del siglo III. Busto a la dcha. con cabeza radiada, imposible identificar a no ser que fuese la de Filipo. Se corresponde con la $n .^{\circ} 8$ de la lámina XXXII.

13. Nummus de Constancio Gallo. Se corresponde con la $n .^{\circ} 9$ de la lámina XXXII.

14. As imposible de identificar. ¿Será la de Augusto? Se corresponde con la $\mathrm{n}^{\circ} 10$ de la lámina XXXII.

15. As de Claudio I. Se corresponde con la $n .^{\circ} 11$ de la lámina XXXII.

16. Nummus de Arcadio. Se corresponde con la $\mathrm{n} .{ }^{0} 12$ de la lámina XXXII.

17. As de Tiberio. Se corresponde con la $n . .^{\circ} 13$ de la lámina XXXII.

18. Nummus de Valentiniano I. Se corresponde con la n. ${ }^{\circ} 14$ de la lámina XXXII.

19. Nummus de Graciano. Se corresponde con la n. ${ }^{\circ} 15$ de la lámina XXXII.

20. Sestercio de Antonino Pío. Se corresponde con la n. ${ }^{\circ} 16$ de la lámina XXXII. 
También se encontró una estatua de bronce de la diosa Fortuna y un fragmento de inscripción dedicado a Aquae Sacrae ${ }^{85}$.

Estatua de bronce de la diosa Fortuna.

AQVI(s) / SACRI(s) / PATVLCIA / T. F. / V.S.L.M.

(VIVES, 5966)

\section{Balneario de Senhora da Luz (Distrito de Faro, Portugal).}

Este balneario se descubrió a orillas de la playa en 1878. Luego, en 1893, después de realizadas las excavaciones se encontró entre las arenas de las construcciones, una moneda de oro de Teodosio ${ }^{86}$.

Aunque la incluimos en el catálogo, tenemos nuestras dudas de que sea un balneario con manantial termal, ya que por su descripción nos hace pensar que podria tratarse simplemente de unas termas. Ante la duda lo hemos incluido.

- Sólido o tremissis de Teodosio ¿l o ll?

A la vista de todo el catálogo se observará que algúnos hallazgos plantean dudas de si las monedas fueron recogidas en el interior de los manantiales, pero también dudamos si todas las monedas aparecidas allí fueron depositadas como ofrendas o no, como ya dijimos. Por todo ello y por el escaso número de hallazgos y ejemplares, las estadísticas no pueden ser todo lo definitorias que hubiésemos deseado. En todo caso, nos servirán para tomar conciencia de un hecho que sabemos se ha producido y habrá que tener presente en toda investigación futura que se realice. A pesar de todo, los datos extraidos serán lo suficientemente sintomáticos para tenerlos en cuenta, aunque queden abiertos a futuras revisiones tras la búsqueda y aparición de nuevos hallazgos.

Para la realización de esta búsqueda recomendaríamos inspeccionar detenidamente gran parte de aquellos lugares susceptibles de haber tenido culto a las divinidades de las aguas, bien porque se haya recogido algún ara o porque tengamos algún indicio. Una primera guía para iniciar este paso sería el estudio de Gloria Mora ${ }^{87}$, sin olvidar que existe una tradición de publicaciones sobre manantiales termales iniciada en el siglo

${ }^{85}$ Para más información bibliográfica se puede recurrir al trabajo de Frade, Helena, op. cit., (Coimbra, 18-20, octubre 1990), n. 40 (en prensa).

${ }_{86}$ Estacio da VeIGa, S., "Antiguidades monumentâes do Algarve", AP, XV. Lisboa 1910, pág. 219; Estacio da VeIga affonso Dos Santos, M. Luisa, Arqueología romana do Algarve, AAP, 2 vols., 1971-72, pág. 110.

${ }^{87}$ MorA, Gloria: «Las termas romanas en Hispania», AEA, 54, 1981, pág. 37-86. 
XVII por el Dr. Limón Montero ${ }^{88}$ y por el Dr. Gómez de Bedoya ${ }^{89}$, quien curiosamente recoge los informes numismáticos que dio Francisco Fornes sobre hallazgos producidos en la provincia de Cuenca, la lástima es que no fuesen en fuentes termales. Contamos con otros trabajos del siglo XVIII, como el de Juan de Dios Ayuda ${ }^{90}$, y muchos más del siglo xix. De tal forma es tan copiosa esta bibliografía que, según nos dice el Sr. Martínez Reguera en Bibliografía hidrológica biomédica española, indispensable su consulta para todo lo relacionado con aguas termales, hay 566 obras sobre el particular durante los primeros dieciocho siglos de la era cristiana, entre impresos y manuscritos, y sólo del siglo XIX se contaba, en el momento en que escribió su obra, con 6.170, entre ellos habría que destacar la de Pedro M. ${ }^{a}$ Rubio ${ }^{91}$. En definitiva, todo este interés por la Hidrología Médica dio lugar a la fundación, a finales del siglo XIX, del Cuerpo de Médicos-Directores de Baños que con sus informes y memorias han contribuido enormemente a dar mayor conocimiento a la ciencia Hidrológica y a editar los folletos del Censo de aguas minerales ${ }^{92}$.

\section{ESTUDIO}

De los treinta y un casos mostrados en el catálogo, dos aparecieron en lagunas y seis en ríos, los veintitrés restantes que suponen el 74,19 por 100 en manantiales. Tenemos dudas de si el de la Hermida es una posible ofrenda a la fuente termal o al río Deva, aunque también puede que su ocultamiento se deba a otras razones. Por otro lado, este hallazgo, como el de la fuente «El Sarso», el de Fortuna y el del Manzanares son

${ }^{85}$ Considerado el padre de la actual Hidrologia por su libro: Espejo cristalino de las aguas termales.

${ }^{89}$ Con su gran obra-diccionario hasta la letra $F$ que dejó sin concluir por culpa de la administración, como él nos dice en el 2. ${ }^{\circ}$ vol. de su obra (Gómez de Bedoya y Paredes, Pedro, Historia universal de las fuentes minerales de España. Santiago de Compostela, 2 vols., 1764-1765).

${ }^{90}$ AyudA, J. de D., Examen de las aguas medicinales de más nombre que hay en las Andalucias.

${ }^{91}$ Rubio, Pedro M., Tratado completo de las fuentes minerales de España.

${ }_{92}$ Para que nos hagamos una idea, en el libro realizado por los Médicos Directores de Baños, entregado a los miembros del XIV Congreso Internacional de Medicina (Abril de 1903): Reseña de los Principales Balnearios de España Madrid. 1903, se clasifican doscientos treinta, los más importantes que habia entonces en España, según sus diferentes propiedades, especificando para que enfermedades sirven, la temperatura de sus aguas y cual es la temporada de uso oficial de las mismas. 
los únicos que reconocemos claramente como aparecidos fuera del agua (fig. 26).

Los hallazgos en rios y lagunas, aunque ofrecen alguna posibilidad de ser ofrendas, entendemos que no todos son muy fiables, por eso conviene recibirlos con cautela. Alguno de ellos pudiera interpretarse que se debe al movimiento del cauce de un río que afectó a un yacimiento próximo o a la limpieza de escombros vertidos al mismo procedentes de poblaciones con bastante antigüedad. Conocemos algunos casos más que preferimos no incluir porque nos plantean serias dudas, como el hallazgo de un as de Tiberio de la ceca de Calagurris con resello de cabeza de águila ${ }^{93}$, además de una moneda romana de cobre, una fíbula y un alfiler que se encontraron en el rio Torto (Concelho de Valpaços, Portugal) ${ }^{94}$.

De las monedas recogidas en los manantiales, el 78,26 por 100 corresponden a posibles ofrendas efectuadas en manantiales hipertermales, sin poder definirnos sobre otras dos por falta de información. Es decir, los casos en que se han realizado ofrendas a manantiales hipertermales constituyen una abrumadora mayoría.

A la hora de realizar el estudio nos fijaremos principalmente en los manantiales. De éstos creo que no interesa contar el total de monedas recuperadas, porque los testimonios que tenemos por cada caso son muy limitados. Basta recordar lo ocurrido en la fuente termal de Cuntis de la que sólo conocemos cinco piezas de no menos de quinientas. Además, si incluyésemos el depósito monetario encontrado en el Balneario de Fortuna, sin diferenciarlo de las piezas sueltas, desvirtuariamos la muestra. Así que hemos preferido contabilizar cada caso por uno cuando el siglo esté representado con alguna moneda (fig. 24), de este modo obtendremos un gráfico con información global pero homogénea. De acuerdo con él, vemos que hay mayor representación en el catálogo de los siglos 1 a. C. al $\| \mathrm{d}$. C., es decir, corresponde a este período el momento en que más ofrendas se hizo a las divinidades de los manantiales o fuentes termales, percibiéndose un ligero aumento de las mismas a mediados del siglo IV. Pero si por un momento, nos olvidásemos de todo lo dicho anteriormente e hiciésemos un cómputo total por siglos de todas las monedas recogidas, nos encontrariamos que la mayoría corresponden, también, al mismo período. En él encontramos el momento de ascenso en el siglo । a. C., sigue en aumento durante el siglo । d. C. y llega a su cenit

\footnotetext{
93 VILLARONGA, pág. 283, n. 1086.

${ }_{94}$ Botel ho, H., "Numismatica e Archeologia, I. Moedas romanas coloniaes (hispanicas) achadas em Trás-os-Montes e Beira», O Archeologo Português, XII, 1907, pág. 23.
} 
en el 11, desciende durante el siglo III para volver a reanimarse suavemente en la segunda mitad del siglo IV.

Procuramos también comprobar si a través de las inscripciones podriamos conocer las divinidades a las que se acudia para realizar dichas ofrendas monetales. Para tal fin añadimos al catálogo las inscripciones aparecidas en cada uno de los manantiales. De su análisis se desprende que en una gran mayoría de los lugares donde aparecieron ofrendas monetales también se depositaron aras votivas, como se puede contemplar en el mapa de distribución (fig. 25). Éstas se dedicaron principalmente a las Nymphis, encontrándose todas en la zona Oeste de la Península. Otras divinidades recibieron ofrendas en dos lugares distintos, como las dedicadas a las Aquis y a la Fontana o Nymphis Fontanae por la misma zona, a Apollini por el Nordeste y a la diosa Fortuna al Sur, aunque una es una estatua. A las restantes divinidades, como a Bormanicus, a Saluti y Proserpina sólo se les ha hecho un ofrecimiento o varios pero en un único sitio.

Debemos considerar al comprobar el mapa resultante que en el conventus de Lucus Augusti, Bracara Augusta y Tarraco en la Tarraconense y en el de Scallabis, Pax lulia y sobre todo en el de Emerita Augusta en la Lusitania fue donde más se prodigaron estas ofrendas. En ellas, como hemos visto, el culto a las fuentes, ríos y lagunas estaba muy extendido, hasta el extremo de encontrarnos en el anverso de algunas monedas de Emérita, como hecho excepcional, la representación iconográfica y propagandística, en sustitución del busto de Augusto, de la cabeza de frente de un hombre barbado teniendo delante de la boca un ánfora que vierte agua (fig. 1), y en otra, de la misma Colonia, una cabeza femenina hacia la dcha., expeliendo agua por la boca (fig. 2) ${ }^{95}$. Pues bien, según Antonio Delgado, en la primera se quiere ver simbolizado al río Anas (Guadiana) que surcaba la ciudad y en la segunda a una ninfa protectora de la fuente que llevaba el agua a la ciudad ${ }^{96}$.

Si ahora nos fijamos en la composición de las aguas de los manantiales termales donde se han encontrado estas posibles ofrendas, observamos que predominan los que tienen aguas sulfuradas con 60,86 por 100 y entre éstos los que las tienen sulfurado-sódicas. Cuatro cuentan con aguas cloruro-sódicas, uno nitrogenadas y otro bicarbonatadas. Pero eso

\footnotetext{
95 Villaronga, L., pág. 269, n. 1027 y 1031; Álvarez Burgos, F., La moneda Hispánica desde sus origenes hasta el siglo v. Madrid 1987, ed. Vico \& Segarra, págs. 125-126, n. ${ }^{\circ} 782$ y 787, y n. ${ }^{\circ} 791$ y 798 .

96 Delgado, A., Nuevo método de clasificación de las medallas autónomas de España, $2{ }^{\circ}$ vol. Sevilla 1873, pág. 25 y 26.
} 
sí, en lo que coinciden la mayoría es que son manantiales con aguas hipertermales, oscilando su temperatura entre los $15^{\circ}$ y $70^{\circ} \mathrm{C}$.

Hemos intentado comprobar si existía algúna relación o correspondencia entre la composición de las aguas y las divinidades a quienes se hacen las ofrendas, pero no la hemos hallado.

\section{CONCLUSIONES}

A la vista de como se han producido la mayoría de los hallazgos analizados y según se desprende de las fuentes escritas, diriamos que en la península ibérica y sobre todo en la parte Occidental se realizaron en la Antigüedad ofrendas monetales a divinidades de las aguas y fundamentalmente, por las referencias que tenemos, a las divinidades de las fuentes termales. Únicamente nos queda la duda de si la fuente de Peña Cutral en Retortillo (Reinosa, Santander) es termal o no, pues si no lo fuese sería el único hallazgo dentro de una fuente no termal. Se podría entender, con ciertos reparos en algún caso, que también se hicieron arrojándolas al curso de los ríos, depositándolas en la orilla y lanzándolas a las charcas o pantanos. Por otro lado, las monedas que se han encontrado en las fuentes, en contraposición con las recogidas en los ríos, suelen estar en muy mala conservación, hasta el punto de que muchas se desintegran en las manos al estar muy atacadas por los ácidos.

A juzgar por algunos de los hallazgos, se podría creer que las ofrendas más valiosas se procuró depositarlas en lugares seguros o resguardados, como es el caso de la Hermida, de la Fuente de El Sarso, del Balneario de Fortuna y podriamos recordar también el hallazgo del conocido depósito de Oñate.

De acuerdo con la cronología de las monedas y según sus resultados estadísticos, la costumbre o rito de depositar o arrojar "stips" a las aguas, principalmente termales, se practicó en la península lbérica más intensamente entre los siglos $\mid \mathrm{a}$. $\mathrm{C}$. al $\| \mathrm{d}$. C. Este periodo coincide con el momento que más estuvo en boga el uso de las aguas termales, a juzgar por lo que se trató el tema en las fuentes escritas. Al mismo tiempo que se percibe esta moda en la vida diaria, pues Suetonio nos dice que Augusto, a pesar de que por su naturaleza enfermiza no abusaba de los baños, sin embargo, cuando necesitaba templar los nervios tomaba 
baños de mar o las aguas termales de Albula ${ }^{97}$. De Nerón nos dice que cuando reconstruyó su casa en Roma después del incendio, la famosa domus aurea, hizo llegar a las salas de baño agua de mar y de Albula ${ }^{98}$.

Por las aras recogidas en las fuentes termales, sabemos que las divinidades que más se sintieron favorecidas con estas ofrendas monetales fueron las Ninfas y las aguas que más beneficios causaron o por las que se sintieron más agradecidos los visitantes fueron las de aguas sulfuradas-cálcicas, es decir, las que se recomiendan principalmente para los problemas de dermatosis herpética, neurosis y catarros crónicos de las vías respiratorias ${ }^{99} \sin$ que ésto signifique que hubiese alguna relación entre las cualidades de las aguas y las divinidades a quienes se dedicaron las aras.

Finalmente, conviene señalar que son éstas las únicas conclusiones a las que nos atrevemos a llegar partiendo de las informaciones que tenemos. No obstante, deseamos que en un futuro se produzcan más hallazgos en lugares tan particulares como los señalados, fuentes, ríos y lagos, que nos permitan confirmar o desmentir con más precisión nuestras hipótesis. Para que ésto suceda animo desde aquí a los arqueólogos para que busquen este tipo de yacimientos y tengan en cuenta sus ofrendas, tratándolas con cuidado por su mal estado, y no tardando en darlas a conocer como tales.

\section{ABSTRACT}

This paper deals with the finding of thirty one cases of possible monetary offerings to the divinities in the waters of the Spanish peninsula.

The largest number of cases involve springs, which make up $74.19 \%$ of the total, of which $78.26 \%$ are h/perthermal springs with temperatures ranging between 15 and $70 \mathrm{C}$.

Most of these springs are to be found in the West of Spain. They are mainly connected with the Nymphis, except in the North West, where they

\footnotetext{
${ }^{97}$ Actualmente se conocen por Bagni y tienen aguas sulfurosas. Esta costumbre la debió de practicar en Hispania, puesto que se sentaba sobre un taburete de madera al que, empleando una palabra hispánica llamaba, dureta e introducia alternativamente las manos y los pies. Suetonio, De vita..., II, 82, 2.

${ }^{38}$ SUETONIO, VI, $31,4$.

${ }^{9 s}$ Según la reseña de M.D.B.
} 
are offered up to Apollini, to judge from the devotional alters which can be seen.

It would appear, from the coins collected, that the custom of throwing stipes to the deities of the springs was mostly practiced between the 1st century B.C. and the 2 nd century A. D., although a slight increase can be seen towards the middle of the 4 th century A. D.

The thermal springs which benefitted most from the profits of these offerings were those with sulfuric-calcic waters. 


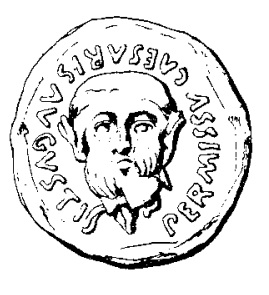

I
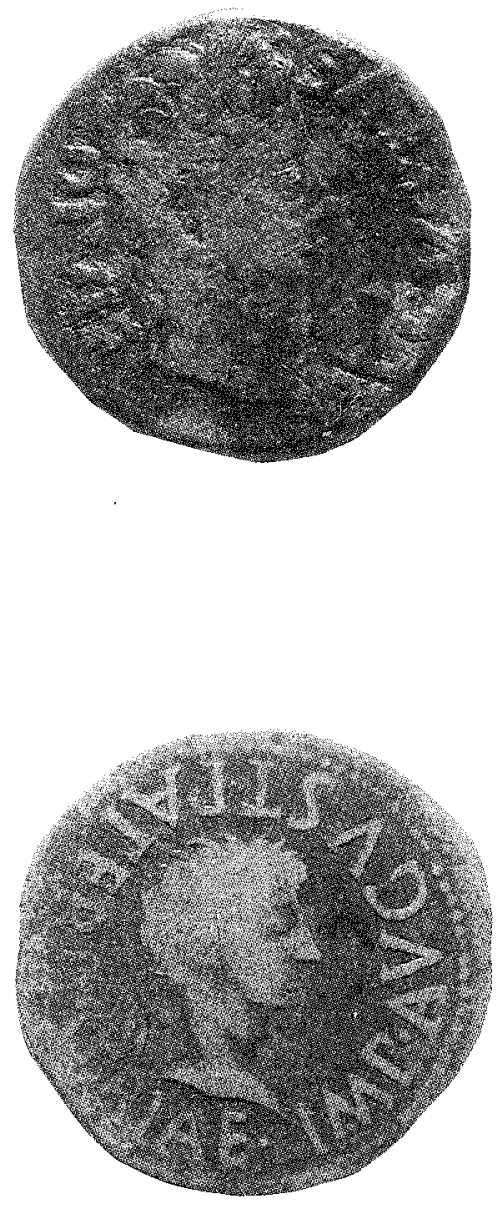

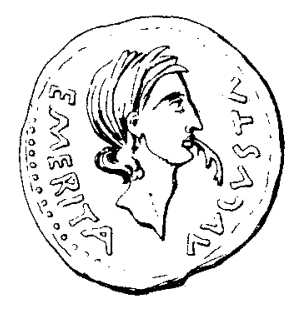

2

3
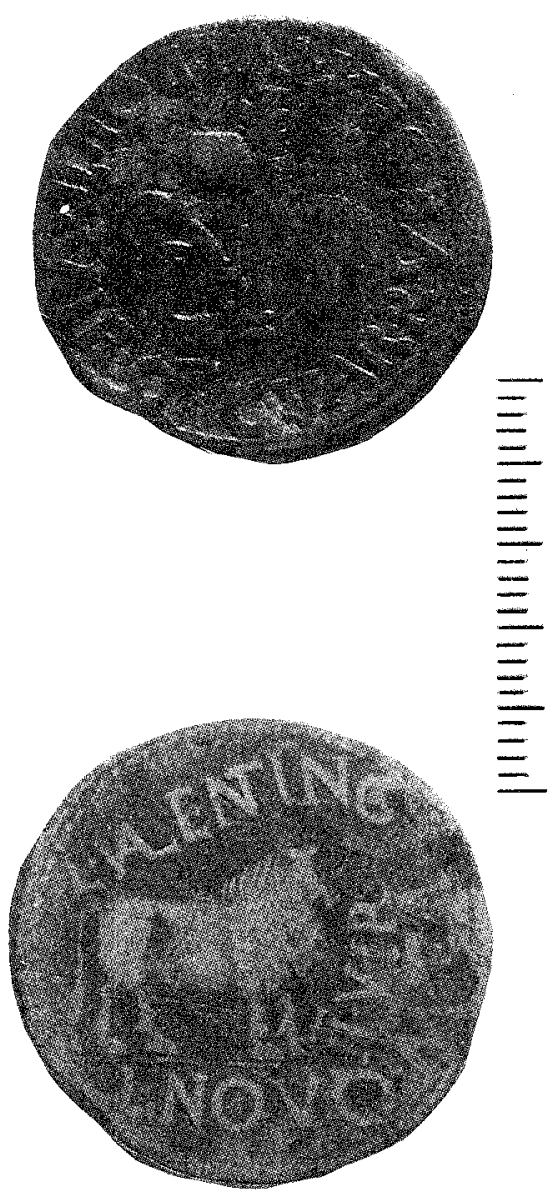


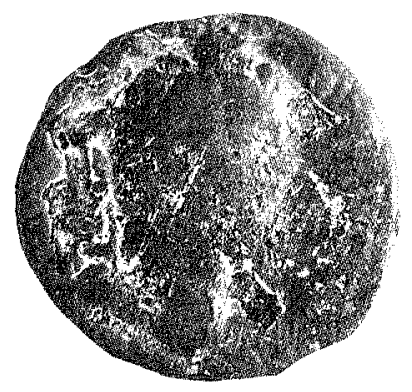

5
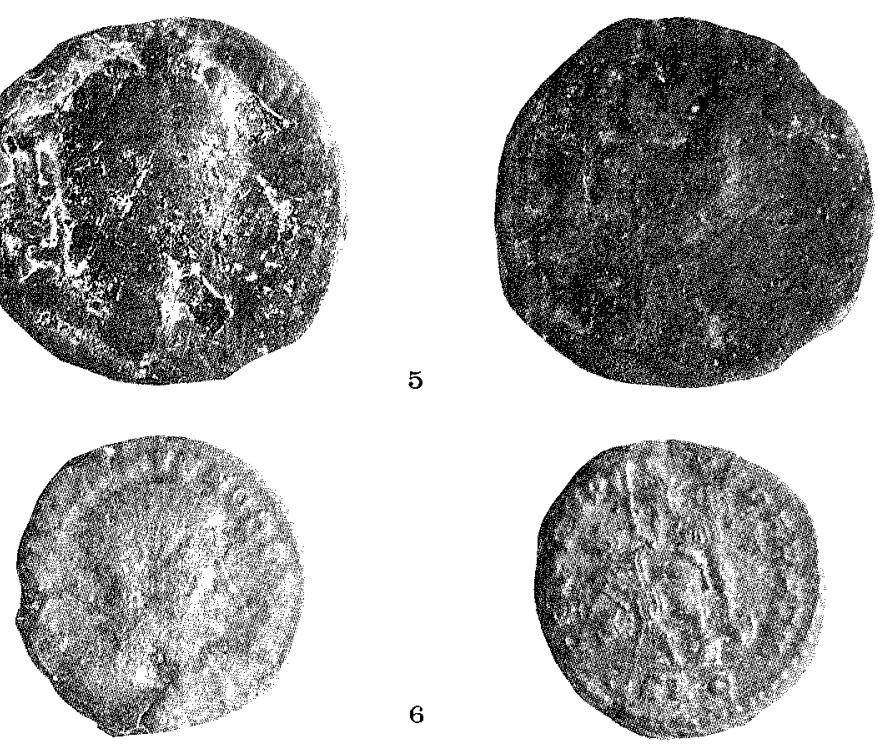

6
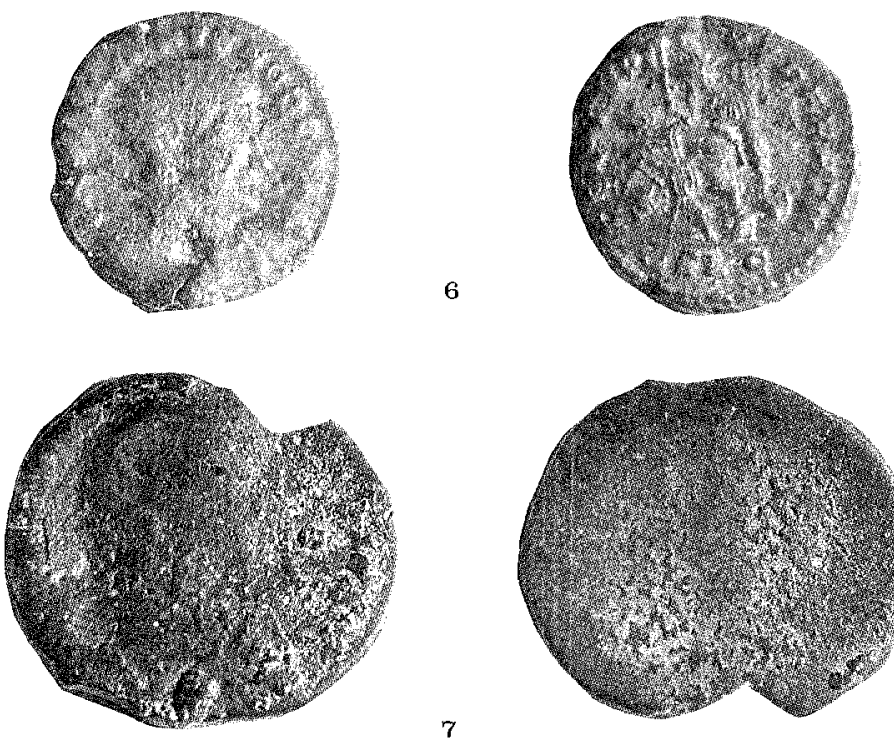

7
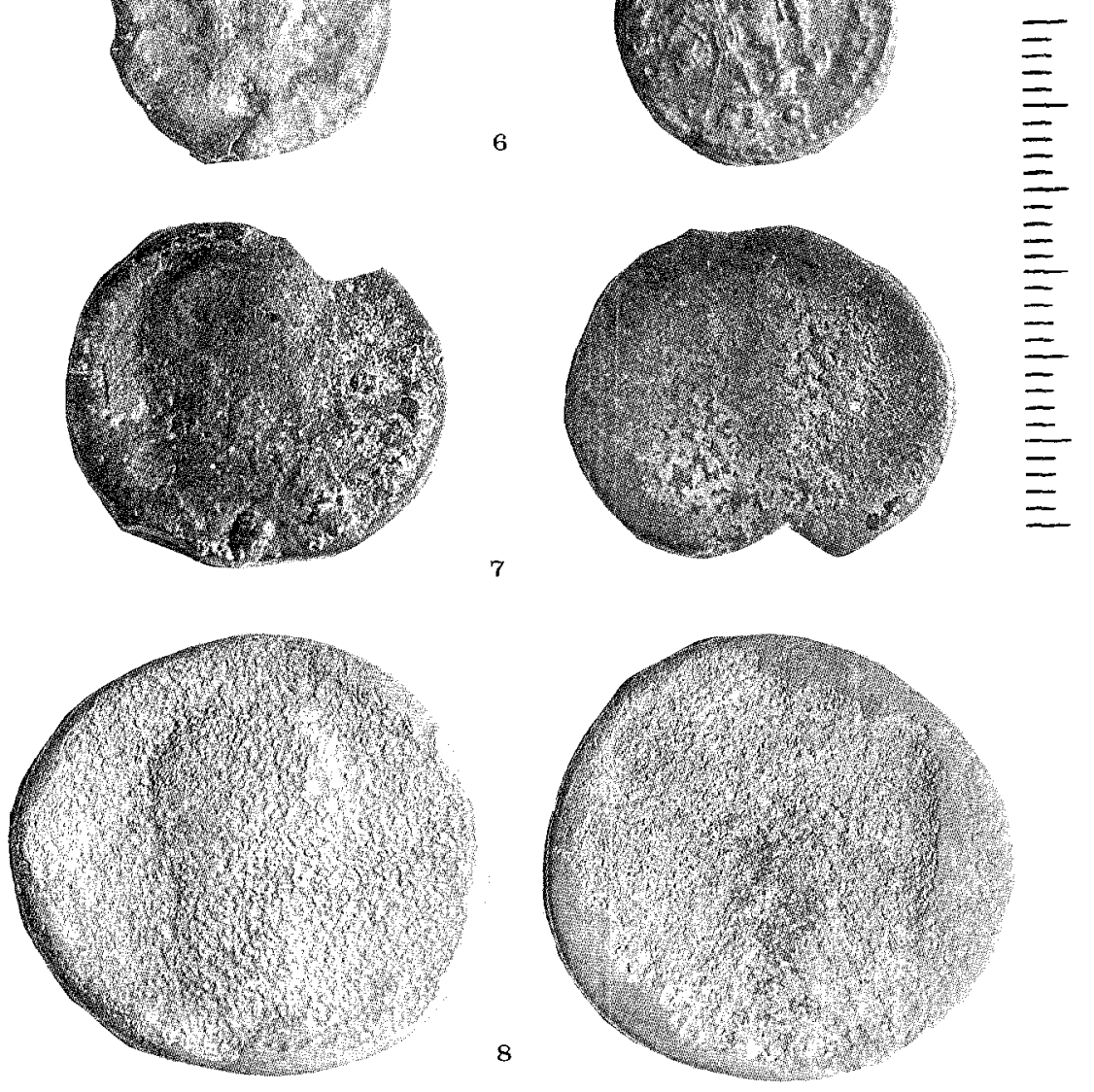


\section{La moneda como ofrenda en los manantiales}

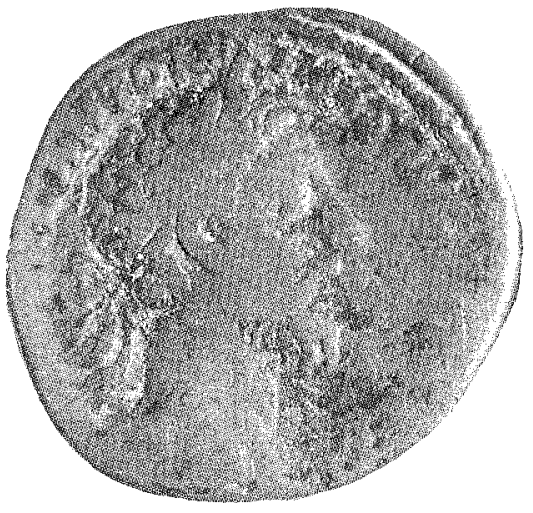

9
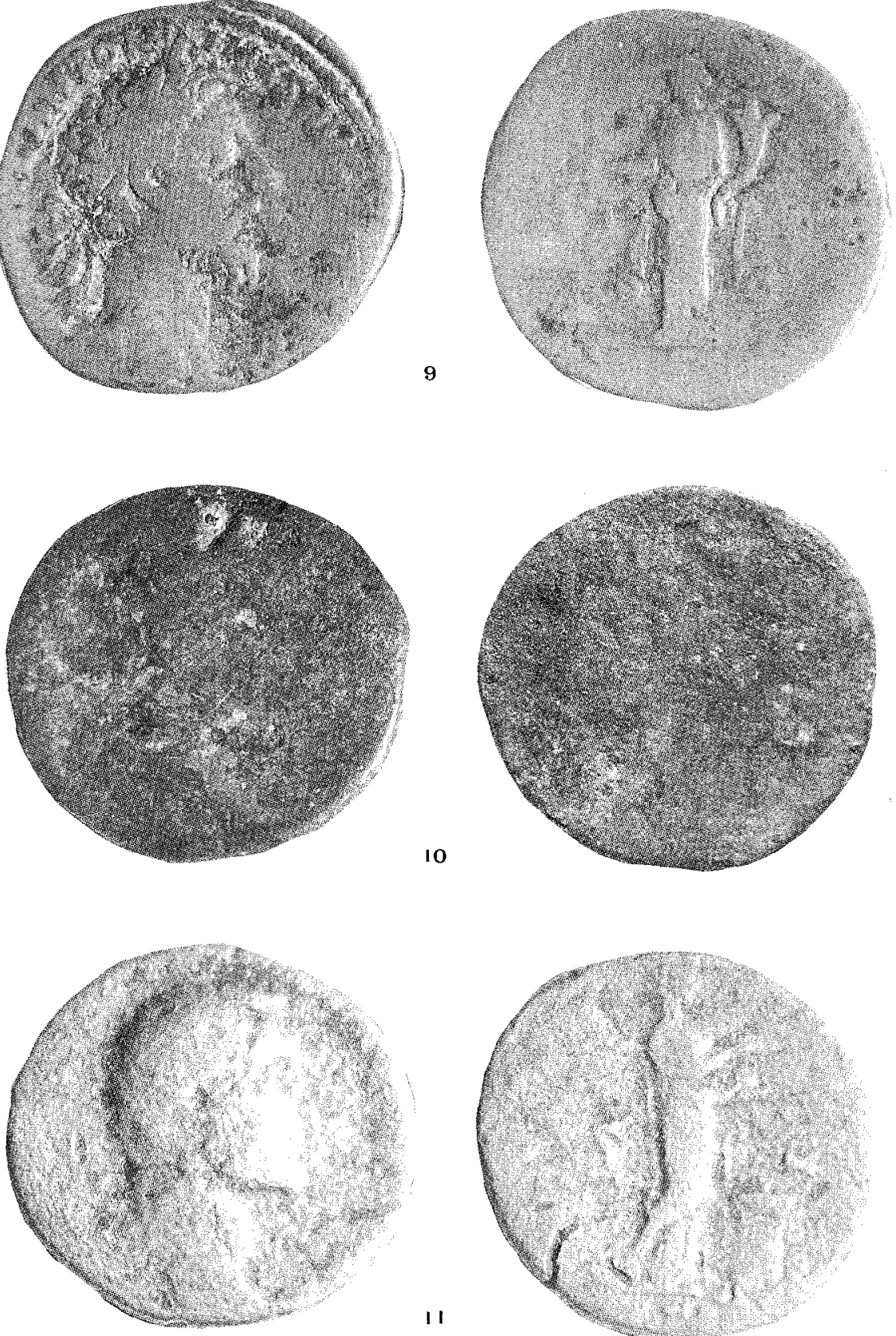

II

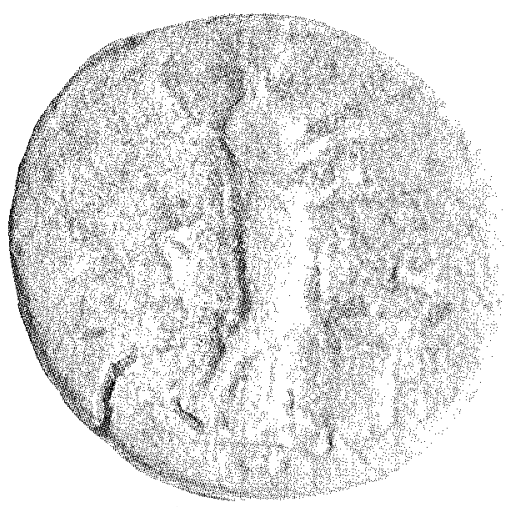




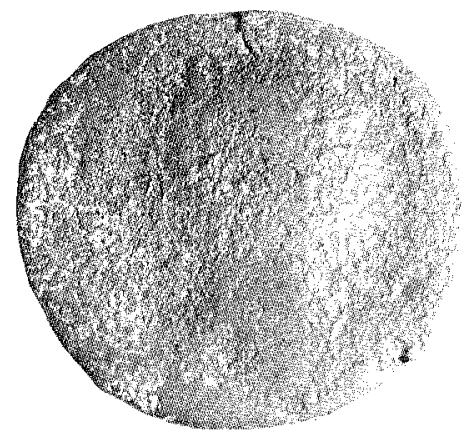

12
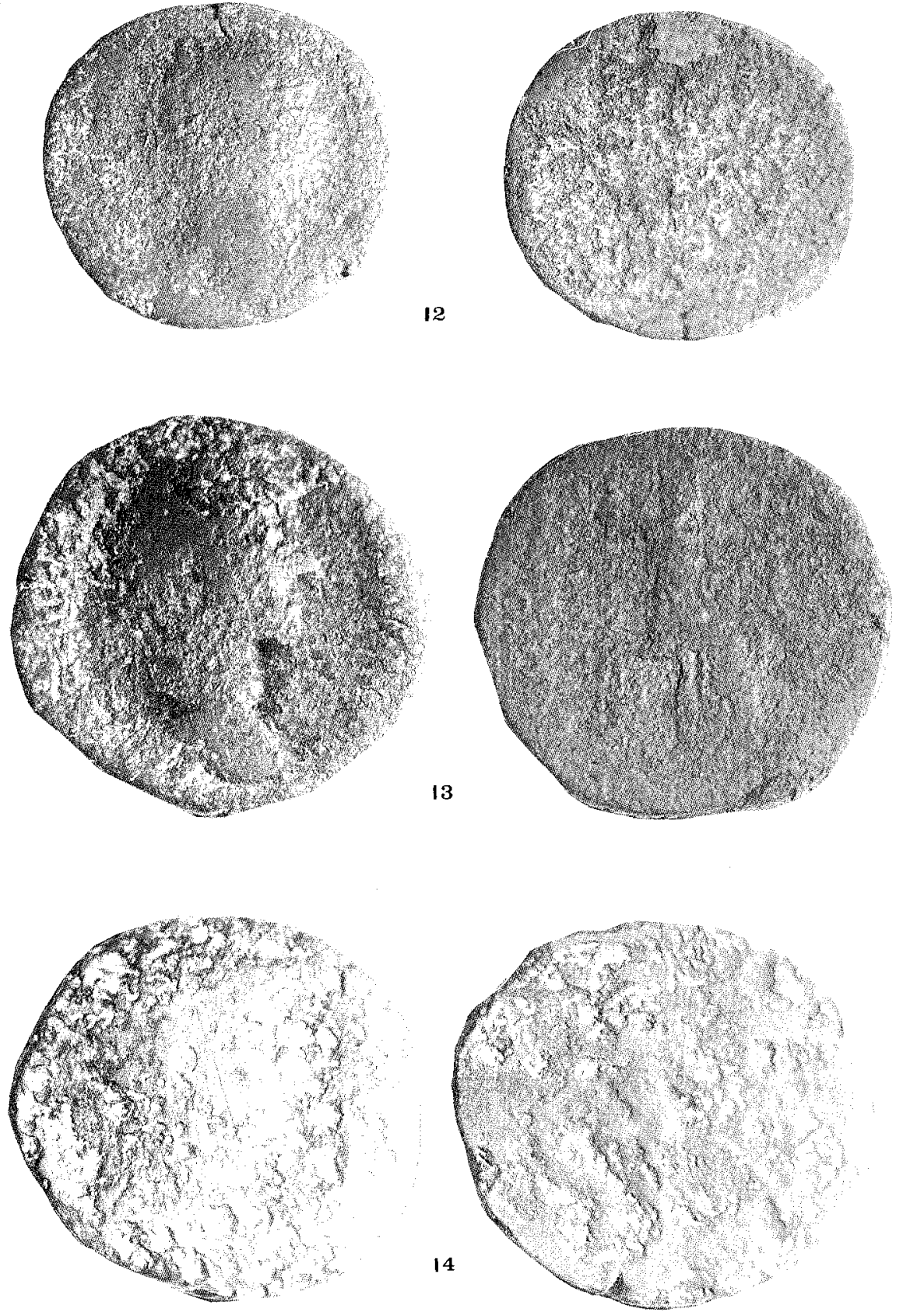


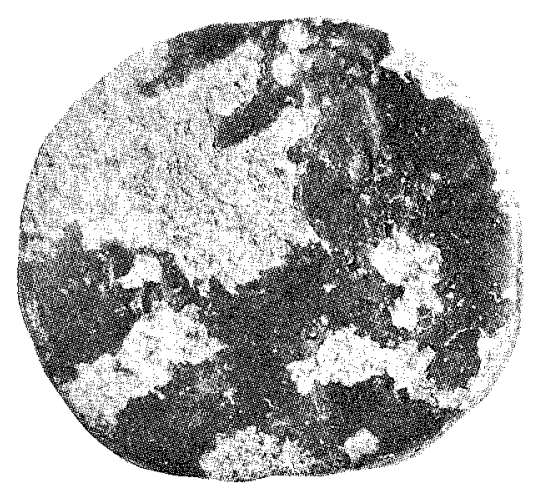

15
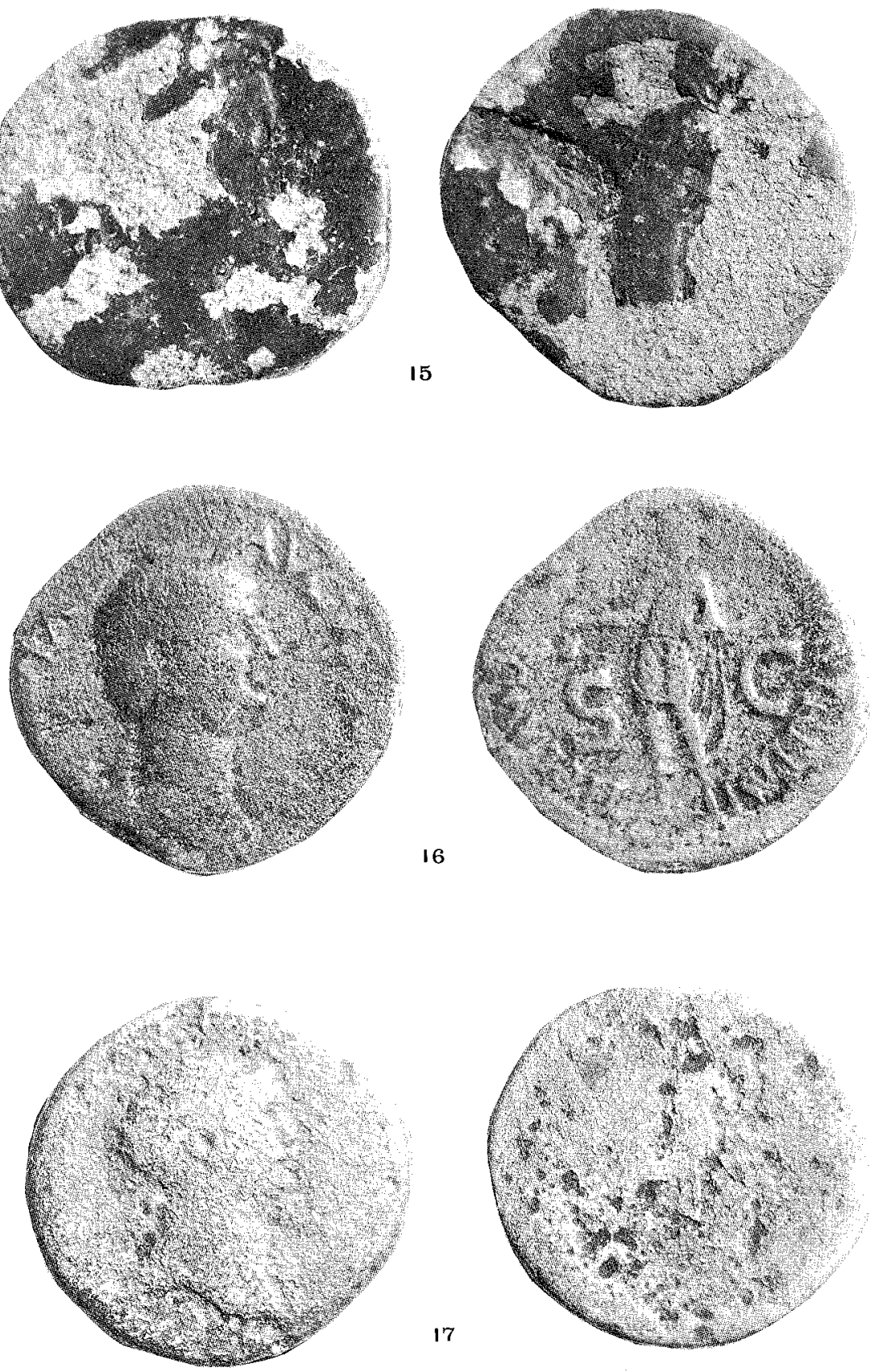

17

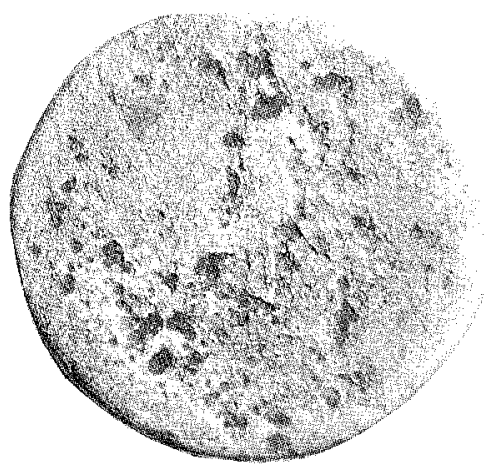




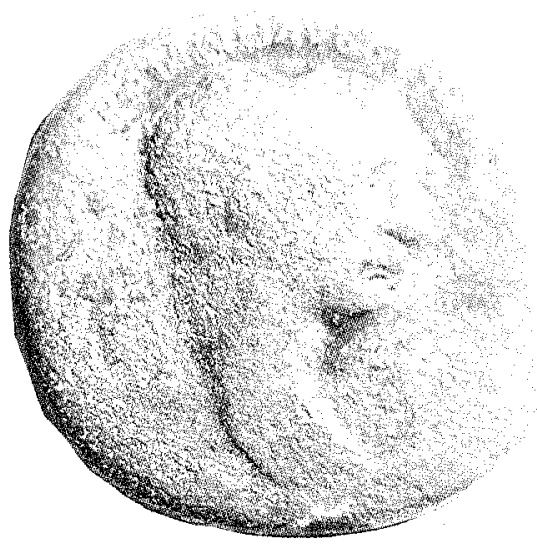

18
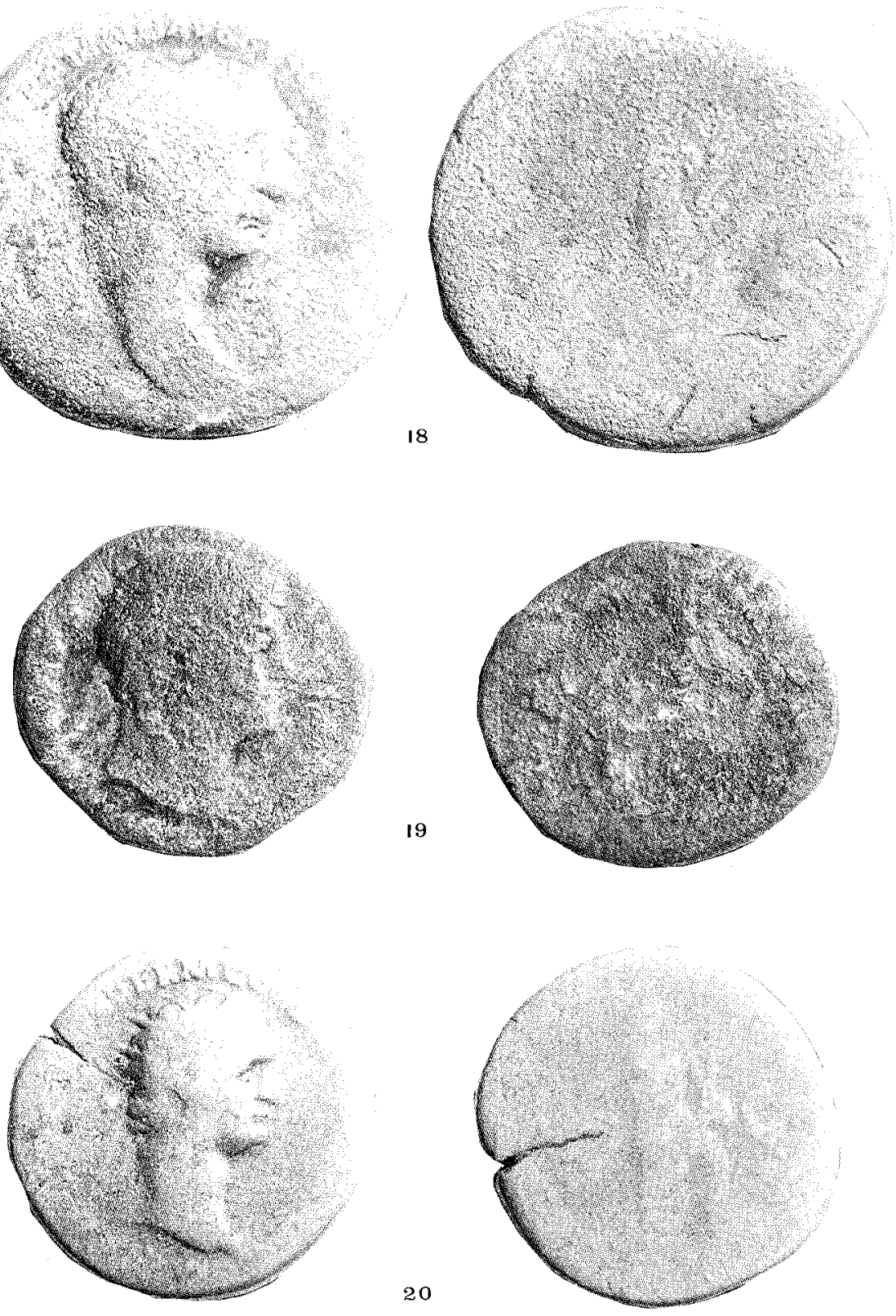


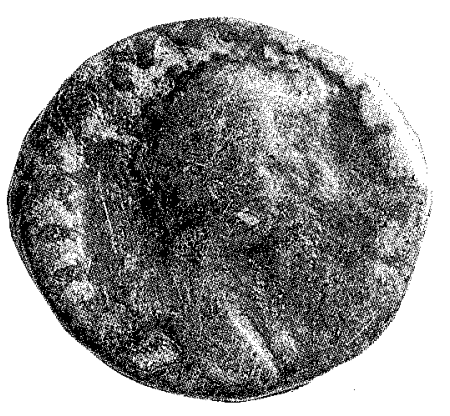

21
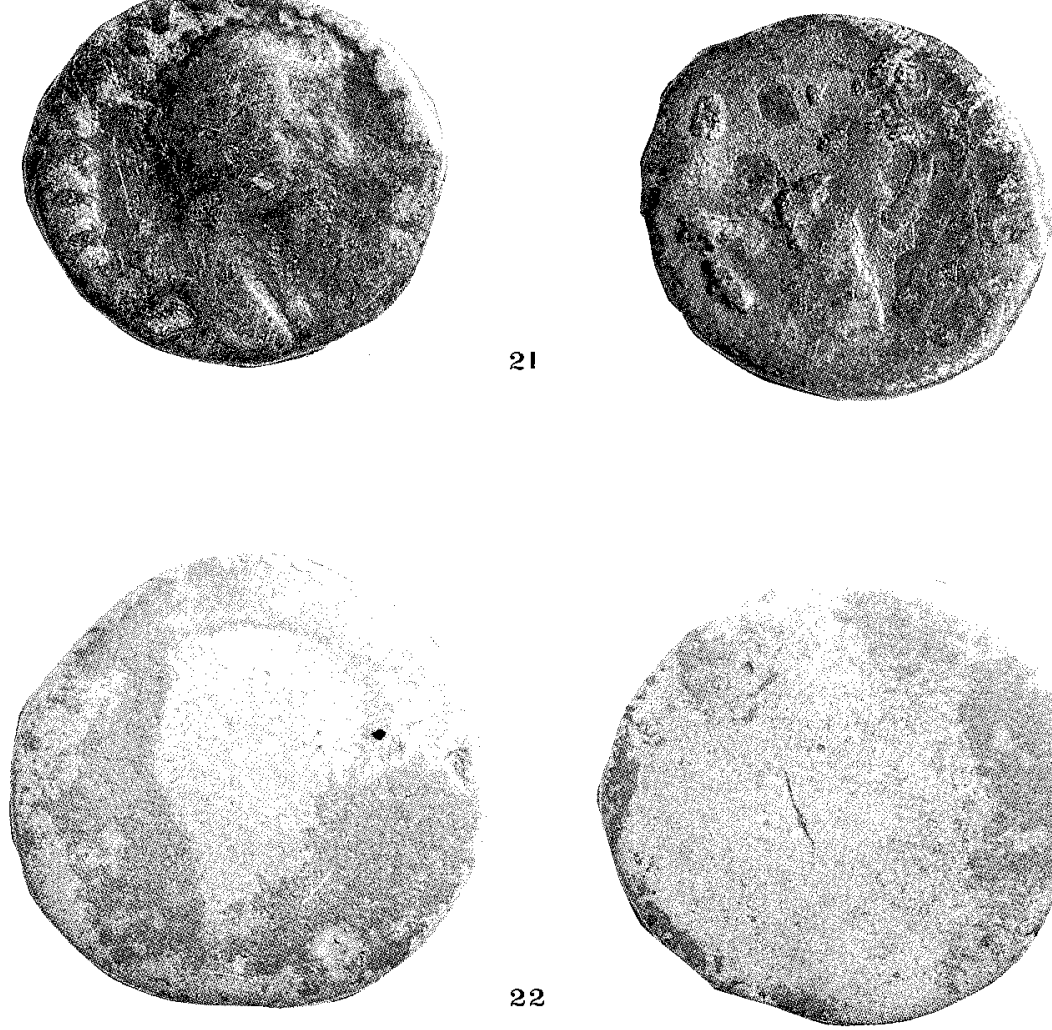

22
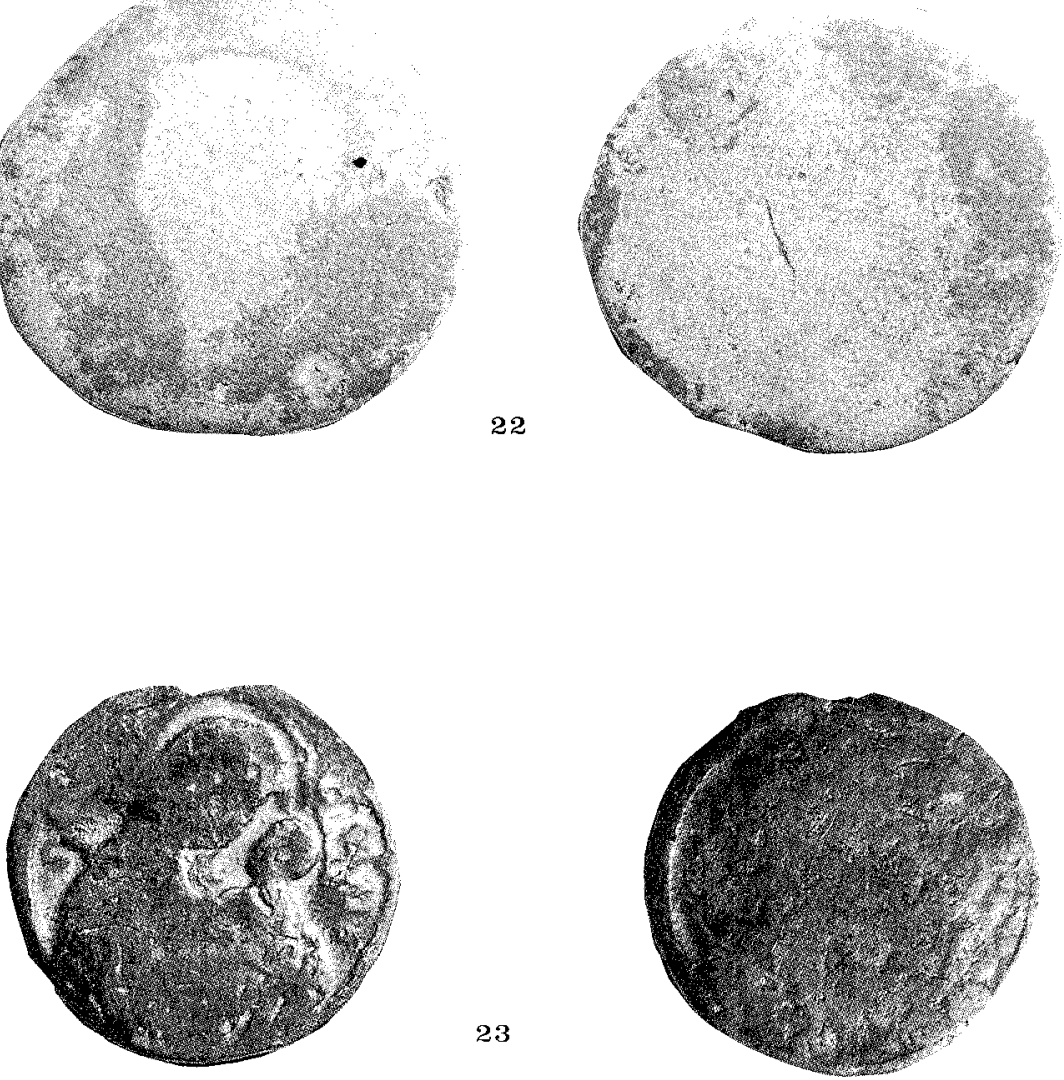

23

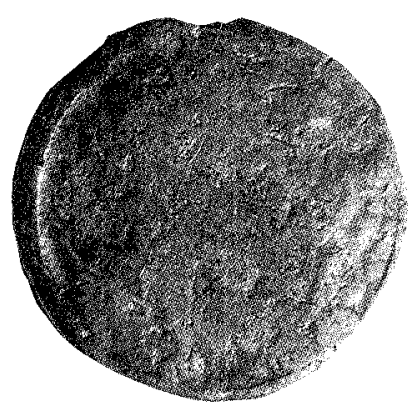




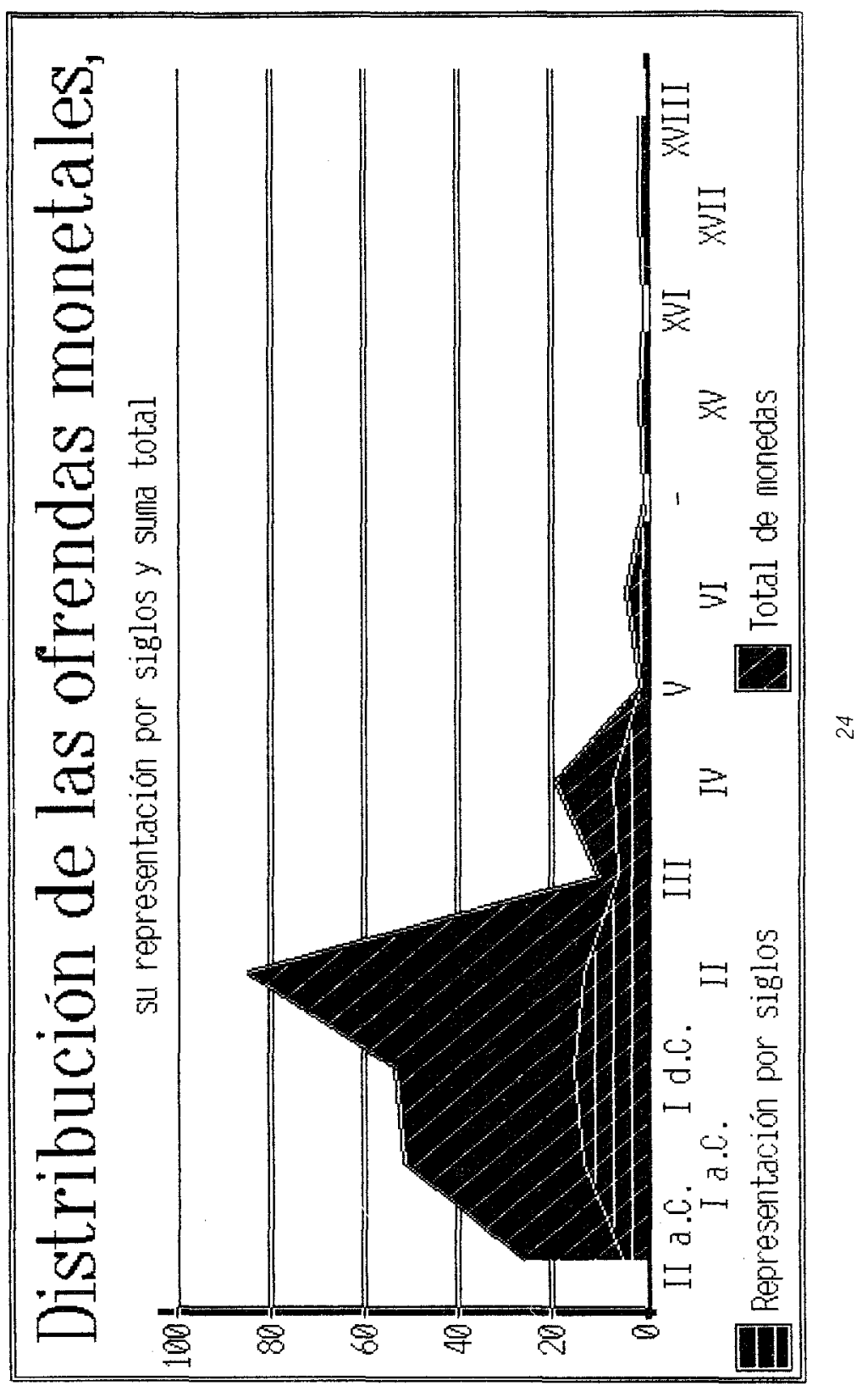




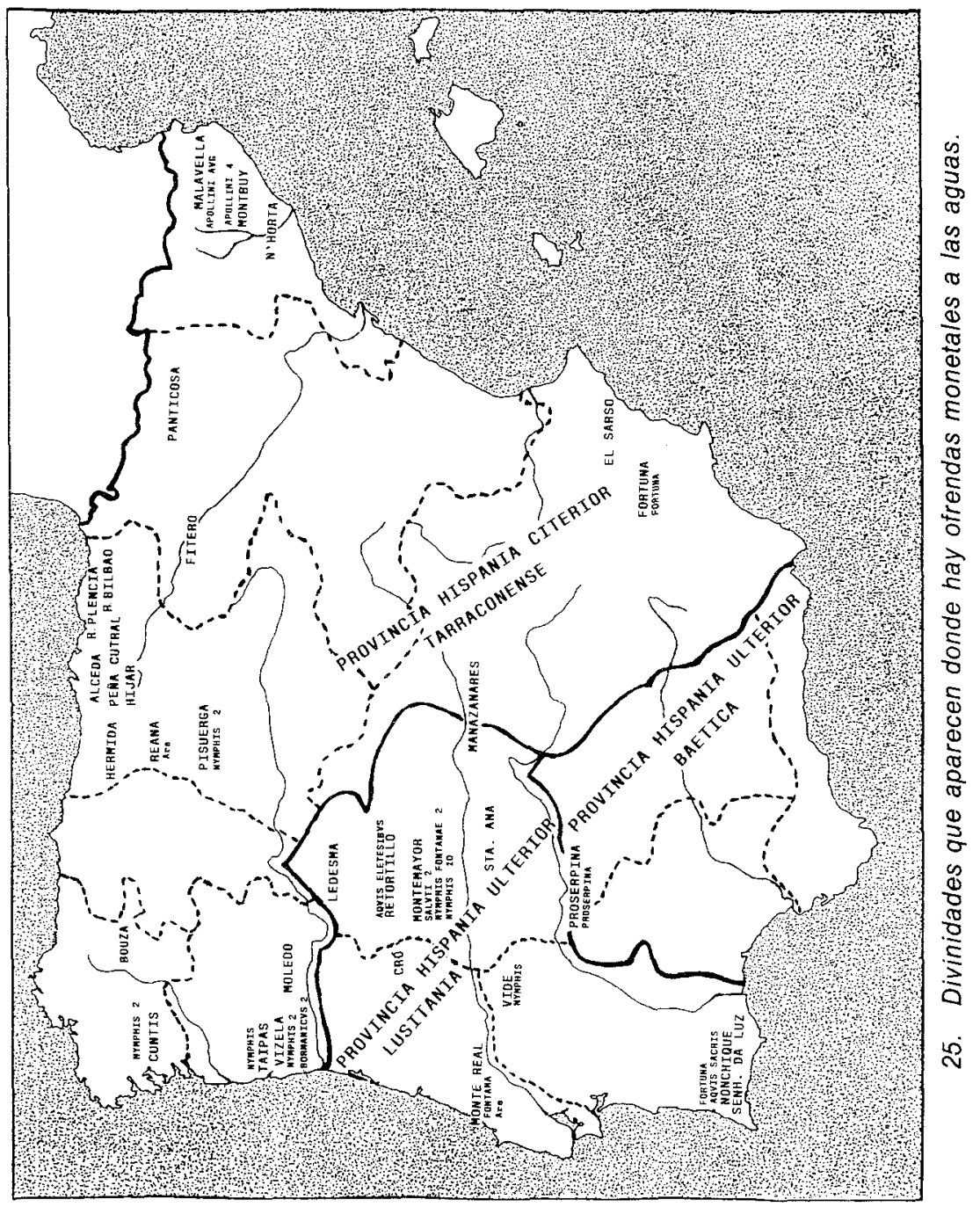




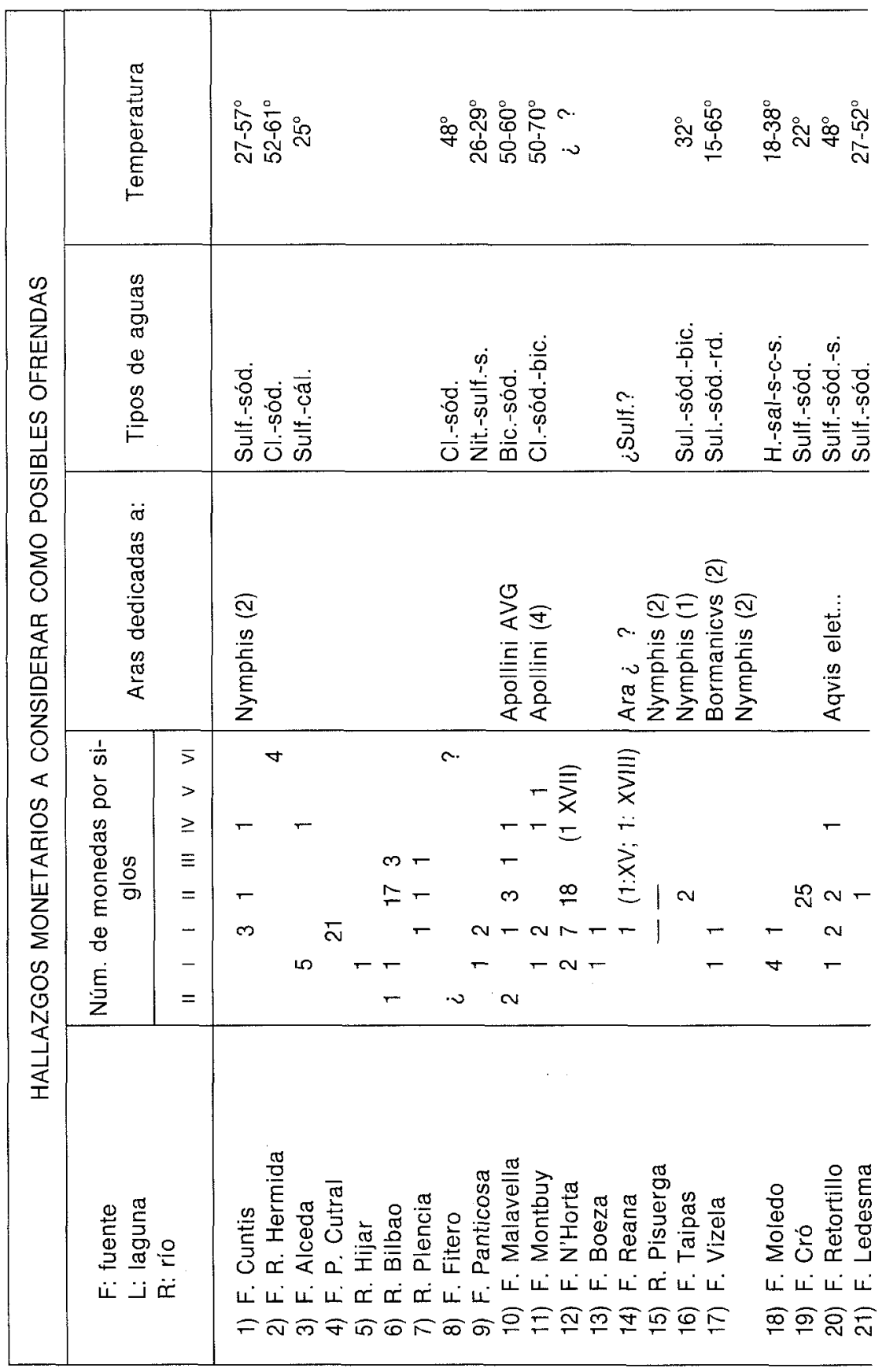


La moneda como ofrenda en los manantiales

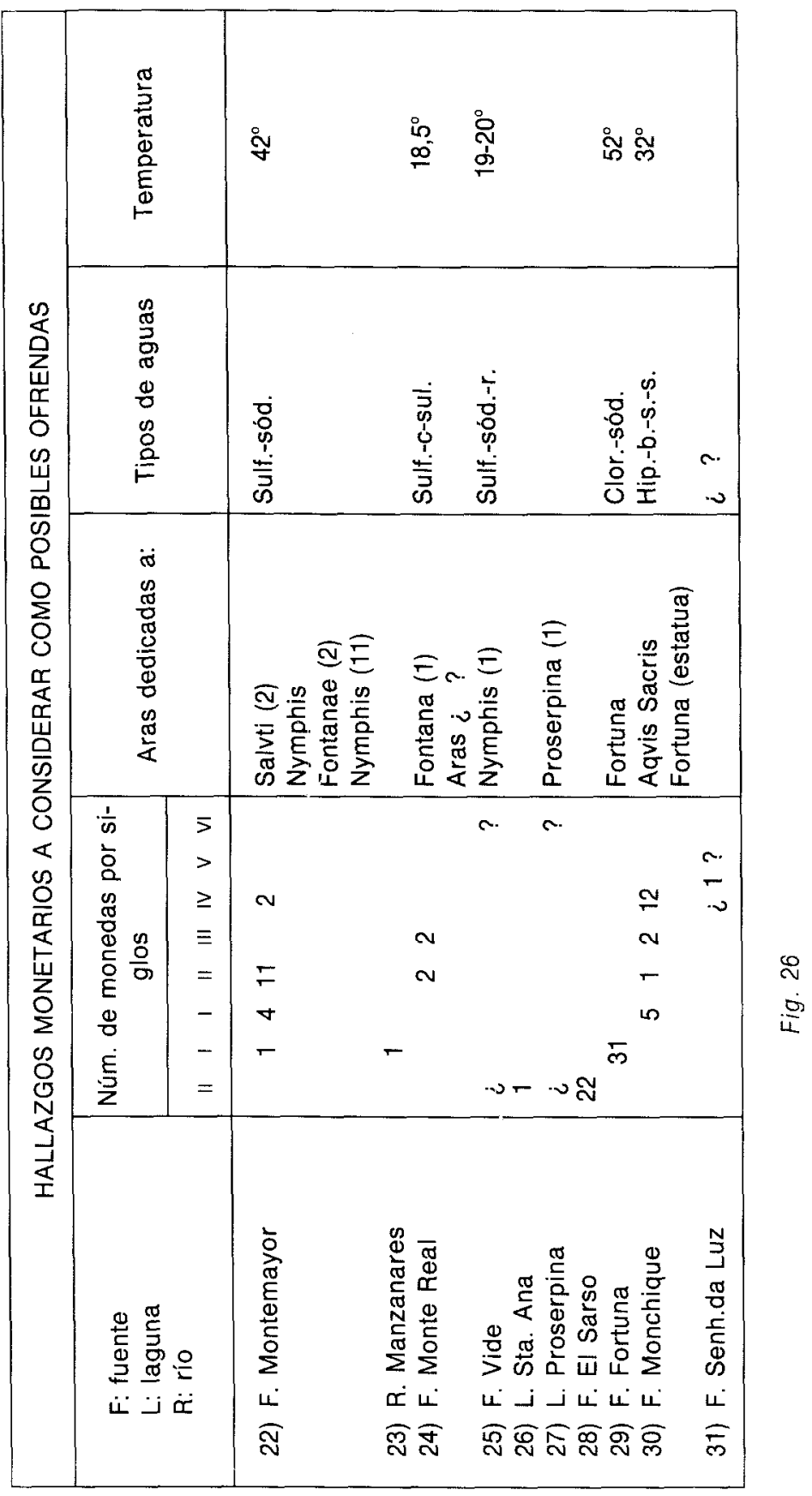

